\title{
Timing and frequency of large submarine landslides: Implications for understanding triggers and future geohazard
}

\author{
Morelia Urlaub $^{*, a}$, Peter J. Tallinga ${ }^{\mathrm{a}}$, Doug G. Masson ${ }^{\mathrm{a}}$ \\ ${ }^{a}$ National Oceanography Centre Southampton, University of Southampton Waterfront \\ Campus, European Way, Southampton SO14 3ZH, United Kingdom
}

\begin{abstract}
Large submarine landslides can have serious socioeconomic consequences as they have the potential to cause tsunamis and damage seabed infrastructure. It is important to understand the frequency of these landslides, and how that frequency is related to climate-driven factors such as sea level or sedimentation rate, in order to assess their occurrence in the future. Recent studies have proposed that more landslides occur during periods of sea level rise and lowstand, or during periods of rapid sedimentation. In this contribution we test these hypotheses by analysing the most comprehensive global data set of ages for large $\left(>1 \mathrm{~km}^{3}\right)$ late Quaternary submarine landslides that has been compiled to date. We include the uncertainties in each landslide age that arise from both the dating technique, and the typically larger uncertainties that result from the position of the samples used for dating. Contrary to the hypothesis that continental slope stability is linked to sea level change, the data set does not show statistically significant patterns, trends or clusters in landslide abundance. If such a link between sea level and landslide frequency exists it is too weak to be detected using the available global data base. It is possible that controlling factors vary between different geographical areas, and their role is therefore hidden
\end{abstract}

\footnotetext{
*Corresponding author

Email address: m.urlaub@noc.soton.ac.uk (Morelia Urlaub)
} 
in a global data set, or that the uncertainties within the dates is too great to see an underlying correlation. Our analysis also shows that there is no evidence for an immediate influence of rapid sedimentation on slope stability as failures tend to occur several thousand years after periods of increased sedimentation rates. The results imply that there is not a strong global correlation of landslide frequency with sea level changes or increases in local sedimentation rate, based on the currently available ages for large submarine landslides.

Key words: submarine landslides, sea level, tsunami, timing

\section{Introduction}

Submarine landslides include the largest mass flows on Earth and can be far larger than landslides on land (Hampton et al., 1996). For instance, the Storegga slide offshore Norway has a volume of over $3,000 \mathrm{~km}^{3}$, and covers an area larger than Scotland (Haflidason et al., 2004). For comparison, collapse of the Mt St Helens volcano in 1980 involved $\sim 3 \mathrm{~km}^{3}$ (Voight et al., 1985), whilst the annual global flux of sediment from rivers into the ocean is $\sim 11 \mathrm{~km}^{3}$ MillimanSyvitski1992, Tallingetal2007. Submarine landslides can generate damaging tsunamis and therefore pose a significant geohazard. The Storegga slide produced a tsunami that locally had ran up of $20 \mathrm{~m}$ around the North Sea coasts, $\sim 8100$ years ago (Haflidason et al., 2005). A slump containing $5-10 \mathrm{~km}^{3}$ of sediment triggered a tsunami that killed 2200 people in Papua New Guinea in 1998 (Tappin et al., 2001). The landslides themselves can damage seafloor infrastructure, such as that used to recover oil and gas, or seafloor telecommunication cables that carry more than $95 \%$ of the global internet traffic. Such cables were broken by a large submarine landslide and the flow of sediment it generated off Grand Banks, Canada, in 1929 (Piper and Aksu, 1987). Numerous hypotheses have been put forward for what causes large submarine landslides, including earthquakes, rapid deposition or gas hydrate dissociation (e.g. Maslin 
et al., 1998; Stigall and Dugan, 2010; Masson et al., 2011). These hypotheses are poorly tested, and even less is known about the effect of other preconditioning factors such as fluid flow focussing in the slope (Dugan, 2012).

It has been proposed that future climatic change and ocean warming may increase the frequency of large submarine landslides, such as through triggering by gas hydrate dissociation (Maslin et al., 1998; Tappin, 2010). It is therefore important to know if past large landslides coincided with major climatic events, or were more frequent during periods of rising sea level. It is also important to understand the timing of large submarine landslides to document their frequency and assess the hazard they pose, and to constrain the factors that precondition and trigger slope failure. The timing of landslides and factors such as sea level or sedimentation rate can potentially provide a test for failure mechanism hypotheses.

Comparisons of landslide frequency with sea level have been undertaken previously by Maslin et al. (2004), Owen et al. (2007), Lee (2009), and Leynaud et al. (2009), who used compilations of between 16 and 43 large submarine landslides. All studies suggest an increased landslide occurrence during periods of glaciation and/or during glacial to interglacial transitions. Several other authors report an increased recurrence interval of submarine landslides from various geographical locations worldwide during sea level lowstand and during sea level rise (e.g. Paull et al., 1996; Prins et al., 2000; Piper et al., 2003; Lebreiro et al., 2009; Henrich et al., 2010; Lee et al., 2010). These studies are largely qualitative and are not supported by any rigorous statistical analysis. Importantly, they do not take fully into account uncertainties in the determination of landslide ages. These uncertainties can be large, as illustrated by changes in understand- 
ing of the age(s) of the Storegga slide. Early studies were based on three cores containing turbidites deposited in an adjacent depositional basin that had no physical connection to the Storegga slide scars. The slide was interpreted as a three-phase event, one of which was older than 30 ka (Bugge et al., 1988). This was then revised by later work that used a more extensive $(>90)$ core data set (Haflidason et al., 2005), to show that the slide was one main event that occurred $\sim 8,100$ years ago. This significant change in age of the Storegga slide is cautionary, as many other slides are dated using small core data sets comparable to that originally used to date Storegga and similar scientific approaches to obtain landslide ages (e.g. Pearce and Jarvis, 1992; Wynn et al., 2002).

Moreover, the age of a landslide is always accompanied by an uncertainty interval as the accurate age determination is complicated by a number of factors. The main uncertainty is typically related to the location of samples, not the uncertainty in the dating method, which is often radiocarbon dating. Samples for dating submarine landslides can originate from its source area (scar) or the depositional zone. They can be taken above the scar as well as above, below or within the landslide deposit (Fig. 1a-d). These dates usually provide minimum or maximum emplacement ages, rather than exact ages. Their proximity to the exact age depends strongly on sedimentology. For instance, the time gap between landslide and sample age will be large if the boundary between pre- and post-failure sedimentation is disturbed by along-slope sediment transport (deposition and erosion), subsequent minor scarp failure or bioturbation (Fig. 1g).

\subsection{Aims}

This contribution assembles a data set of ages for 68 large volume submarine landslides, of which 67 are previously published. The data set also includes new 
radiocarbon dates for the Walker-Massingill slide in the Gulf of Mexico. The ages are derived by dating of the landslide itself, or by dating of the turbidite generated by a landslide. Only landslides (or turbidites) with volumes in excess of $1 \mathrm{~km}^{3}$ are included in this study. Each data point underwent a critical review to avoid interpretation errors and is assigned an individual uncertainty interval.

The first aim is to address the following questions. Given the available ages for these landslides, and taking into account uncertainties in these ages, is there an association between sea level and the timing of seafloor failure? Does landslide frequency vary significantly with sea level, or could the pattern of landslide ages be random and unrelated to sea level? We apply basic statistics to the data set and assess whether the impact of sea level cycles on landslide timing is as strong as previously suggested (Maslin et al., 2004; Owen et al., 2007; Lee, 2009).

The data set is then subdivided to consider the frequency of landslides in different settings that comprise (i) glaciated margins, (ii) river-dominated systems, (iii) sediment-starved margins, and (iv) the north-west African margin where there is an extensive data set. This is done to accomplish the second aim. Is there a significant association between landslide timing and sea level in particular subsets of the data?

We then document available information on changes in sedimentation rate in the vicinity of these large volume landslides. Our third aim is to determine whether there is an association between periods of rapid sedimentation and the timing of landslides, and we analyse the temporal relation of peak sedimentation rates and nearby large scale landslides. This analysis aims to understand whether there is a strong causal link between periods of rapid sedimentation 
and landslides, as has been predicted by some previous models (e.g. Coleman and Prior, 1988; Leynaud et al., 2007; Stigall and Dugan, 2010).

We conclude with a summary of the implications of this work for predicting the likely hazard posed by landslides (and landslide-tsunamis) in the future as sea level rises rapidly.

This paper follows the terminology of Masson et al. (2006). The term 'landslide' is used as a generic term encompassing all forms of slope failure. The terms 'slide', 'debris flow' and 'turbidity current' imply particular failure processes (Masson et al., 2006). Debrites and turbidites are deposits of the latter two processes.

\subsection{Climate change and slope stability}

A variety of factors has been proposed to impact on the stability of continental slopes. One of these factors is sea level change associated with glacialto-interglacial climatic cycles (Mulder and Moran, 1995; Maslin et al., 1998; Vanneste et al., 2006; Owen et al., 2007; Leynaud et al., 2009; Lee, 2009). Here, we analyse the direct and indirect links between eustatic sea level and slope stability. The eustatic (global) sea level curve is used (Waelbroeck et al., 2002), rather than local sea level curves for individual areas, because local sea level curves are not available for some areas. Moreover, local sea levels often reflect a combination of different processes in addition to sea level change, such as isostatic rebound, tectonics or sediment loading. Eustatic sea-level is therefore also a better proxy for large-scale climate changes, including changes in ocean temperature and circulation. 


\subsubsection{Deposition rates}

One factor often assumed as the driving mechanism for submarine landslides is high rates of deposition that cause overpressure in the sediment (e.g. Stigall and Dugan, 2010). This is because rapid sedimentation favours the retention of pore fluid, and development of high excess pore pressures. The amount of terrestrial sediment that is transported into the ocean is mainly controlled by weathering patterns in the hinterlands, which are subjected to glacial-interglacial shifts of climate belts. The interplay with many other factors, for example a regional time delay between climate-driven onshore changes and offshore deposition (e.g. Métiver and Gaudemer, 1999; Castelltort and VanDenDriessche, 2003) make the sedimentation histories of different continental margins variable (e.g. Nittrouer, 2007; Covault and Graham, 2010).

In high latitudes terrestrial sediment input is highest during glacial periods due to erosion at the base of ice sheets which then extend to the shelf edge (Vorren et al., 1998; Weaver et al., 2000; Rørvik et al., 2010). Across-shelf oriented ice streams drain the ice sheets and therewith provide effective transport of eroded material. Consequently, large depocentres of glacigenic sediments (trough mouth fans) develop in front of these ice streams. This process stops as soon as ice sheets retreat, leaving a minor terrestrial input to the ocean by meltwater and a significantly smaller sedimentation rate (Dowdeswell and Elverhøi, 2002; Rørvik et al., 2010). Mulder and Moran (1995) suggest that not only elevated deposition rates at glaciated margins during glaciations but also the weight of the ice sheet causes excess pore pressure in the sediment.

During glacial periods in moderate latitudes the ice was concentrated inland and did not reach the shelves (Clark et al., 2009). Large amounts of sediments 
locked up in these ice sheets are released by meltwater discharge pulses during deglaciation (Lebreiro et al., 2009; Toucanne et al., 2012). At most mid-latitude continental margins deposition rates are thus highest at the end of a glacial, i.e. during the onset of sea level rise (e.g. Ducassou et al., 2009; Lebreiro et al., 2009; Bourget et al., 2011). This is also when most of the big river systems experience highest discharge rates (Covault and Graham, 2010). Contrarily, in some cases the rising sea level may also hamper the sediment coming off the shelf and sedimentation rates decrease (e.g. Nelson, 1990; Rothwell et al., 2000; Reeder et al., 2002).

In low latitudes weathering rates in the hinterland change with climate shifts. River systems may be active or not depending on precipitation rates. The "Wet Sahara" is one example, which describes short pluvial phases with active river systems in an otherwise arid area (e.g. Pachur and Kröpelin, 1987).

Hemipelagic sedimentation rates on continental slopes are generally highest during glacials due to increased productivity, regardless of latitude (Berger and Wefer, 1991). This pattern may change at large water depths (ocean dependent, typically between $3-5 \mathrm{~km}$ ), in which the corrosivity of the prevailing bottom water controls the net-flux of phytodetritus to the seafloor (Berger, 1972). The provenance of such corrosive deep water currents varies spatially and temporally according to climate driven changes in global ocean circulation patterns.

\subsubsection{Location of depocentres}

Not only does the amount of terrestrial sediment delivered to the continental margin changes from glacials to interglacials, but also the location of its deposition (Lee, 2009). In periods of low sea level large areas of the continental shelves are exposed and sediment deposition shifts seaward, by-passing the continental 
slope, and towards the continental toe (Posamentier et al., 1992). This is critical as, when loaded, a slope has a higher potential to fail due to prevailing shear stresses than a nearly flat shelf where shear stresses are absent. During high sea level shelves are flooded and most continental slopes are disconnected from rivers or ice streams (Covault and Graham, 2010), limiting direct delivery of sediment to the continental slope and promoting deposition on the continental shelf. However, some river systems appear to be continuously active at all sea level stands, although with a reduced activity during sea level high stands (e.g. Monterey, Zaire, Covault and Graham, 2010).

\subsubsection{Stress changes}

Previous work has suggested that sea level fluctuations impact on slope stability directly (Weaver and Kuijpers, 1983; Lee et al., 1996), as they alter the stress regime at the seafloor. It is important to understand that sea level fluctuations change hydrostatic pore water pressure (the weight of all the water above). This directly affects the total stress (the total load experienced at a point), which is the sum of the effective stress and the pore water pressure. The fraction of the applied load that is borne by the pore fluid is given by the loading efficiency $\alpha$. For shallow marine sediments $\alpha=0.97$ (Liu and Flemings, 2009 ), i.e. a change in total stress is almost entirely borne by the pore pressure $(97 \%)$ and the effective stress changes only slightly $(3 \%)$. Therefore, from a geomechanical point of view, the direct impact of changing sea level on slope stability is likely to be minimal.

Free gas is affected more strongly by a change in sea level as it depends on total stress. If gas is present in the pore space during sea level fall, the pore pressure drops less than the total stress due to the high compressibility of gas and overpressure develops (Liu and Flemings, 2009). Contrarily, the effective 
stress increases in gas bearing sediments when sea level rises.

\subsubsection{Isostatic adjustment}

When ice sheets retreat the Earth's crust responds elastically to the loss of weight by isostatic rebound. This uplift is most rapid where the ice was thickest, such as in the centre of the continent, and gradually declines towards the continental margin (e.g. Milne et al., 2001), thereby causing steepening of continental slopes and decreasing their stability. However, this slope gradient increase is small; e.g. on the order of $0.1^{\circ}$ for the Norwegian continental margin. We calculate this using the total uplift of $0.76 \mathrm{~km}$ in the past $13 \mathrm{ka}$ at the centre of uplift at the Swedish Baltic coast (Mörner, 1979), and a distance of about $400 \mathrm{~km}$ to the Norwegian continental slope, where the uplift is nearly zero.

The crust also responds in a brittle manner to crustal stress changes by generation of earthquakes (Bungum et al., 2005). Seismic shaking can cause an increase in pore pressure as well as a decrease in the sediment's strength and is therefore capable of triggering a submarine landslide (Biscontin et al., 2004).

\subsubsection{Bottom water temperature}

A change in global surface temperature is followed by a gradual and slow temperature change of the bottom water in the oceans and at the seafloor (e.g. Clark et al., 2009). A bottom water temperature increase leads to a downslope shift of the gas hydrate stability zone and will cause dissociation of hydrates at the base of the hydrated layer (Kvenvolden, 1993). However, Reagan and Moridis (2008) showed that in the case of thick hydrated layers in large water depths $(>600 \mathrm{~m})$, the released gas will migrate back into the stability zone to form hydrate again. If the layer is thin (in water depths $<600 \mathrm{~m}$ ) a temperature increase of as little as $1^{\circ} \mathrm{C}$ can cause the release of significant amounts of free 
gas that can promote slope instability.

During the retreat of ice sheets, hydrate destabilisation due to a temperature increase is counterbalanced by an increase in pressure due to sea level rise. Nevertheless, this stabilising effect is small and can only delay a release of methane, especially in shallow water (Kvenvolden, 1993; Reagan and Moridis, 2008).

\subsubsection{Bottom water currents}

Strong intermediate and deep water bottom currents can erode sediment at the toe of the slope and therewith undercut and destabilise the slope (Hampton et al., 1996). A climate-ocean circulation link is widely accepted (e.g. Rahmstorf, 2002) and glacial-interglacial variability of bottom current strengths has been reported from various locations (McCave et al., 1995; Gröger et al., 2003). However, the way in which bottom current strengths are affected is complex and spatially variable, i.e. during glacials bottom currents can be stronger (Revel et al., 1996) or weaker (McCave et al., 1995; Gröger et al., 2003).

\subsubsection{Groundwater flow}

Groundwater seepage may contribute to excess pore pressures within a continental slope (Locat and Lee, 2002). Drainage patterns depend on head differences between continental groundwater and sea level, which increase during sea level fall (Lee, 2009). In addition, DeFoor et al. (2011) show evidence that ice sheet meltwater infiltrated into the continental groundwater, and was discharged as submarine groundwater in the Greenland Shelf. The authors report a twofold increase in discharge rate during the Last Glacial Maximum compared to ice-free conditions. 


\subsubsection{Climate-independent causes}

Seismicity is generally controlled by tectonics and thus assumed independent of climate, unless associated with glacial loading or rebound. A trigger mechanism such as an earthquake would be expected to produce randomly distributed landslides. Exceptions are glaciated regions, where seismicity is controlled by a retreat of the ice sheet. Oversteepening due to salt doming or other tectonic activities as well as a stress-related collapse of mechanically weak layers are other climate-independent failure mechanisms.

\subsection{Dating submarine landslides}

Several approaches can be used to estimate the timing of submarine landslides. The most appropriate strategy is to determine the age of the hemipelagic sediment that is (i) immediately overlying and/or underlying the landslide deposit in sediment cores from the deposition zone, or (ii) overlying the landslide scar or surface along which sediment has been removed in sediment cores from the source area. Three methods are widely used for the age determination of hemipelagic sediment. The uncertainties involved with each dating method are firstly described, followed by (often larger) uncertainties arising from the location of the sediment samples within the core.

\subsection{1. ${ }^{14} C A M S$}

${ }^{14} \mathrm{C}$ Accelerator Mass Spectrometry (AMS) dating of microfossil shells is the most widely used tool to determine the absolute age of marine sediments younger than $50 \mathrm{ka}$ (e.g. Thomson and Weaver, 1994). This method can date sediments to an age of up to 50 ka with typical measurement uncertainties of \pm 100 years. A calibration (e.g. Reimer et al., 2009) as well as a reservoir correction for conversion to calendar years is necessary (Lassey et al., 1990). These corrections vary both temporally and locally and are the main reasons for the uncertainty 
of calibrated dates in marine sediments, which is typically in the order of \pm 500 years. Bioturbation is another potential error source.

\subsubsection{Oxygen isotopes}

Oxygen isotope stratigraphy is the preferred method for dating marine sediments older than 50 ka, and those with a low biogenic content (Prell et al., 1986). The amount of ${ }^{18} \mathrm{O} /{ }^{16} \mathrm{O}$ in hand picked calcareous shells of microorganisms is measured in a mass spectrometer and the resulting isotope record has a dominant glacial-interglacial signal (Shackleton and Opdyke, 1973). The relationship of this isotope record to age is obtained by orbital tuning (e.g. Imbrie et al., 1984). The isotope content is measured preferably on benthic foraminifera as, while alive, they were subjected to a much smaller range of temperature due to relatively stable deep water temperatures (Shackleton and Opdyke, 1973).

Uncertainties in this method may arise from bioturbation that mixes foraminifera up or down the core. For instance, Hutson (1980) reports a 4.5 ky uncertainty for oxygen isotope stratigraphy due to bioturbation at oxygen isotope stage boundaries. Uncertainties will be higher for cases with relatively low abundance or variations in abundance of the species on which the isotopes are measured (Hutson, 1980). Differences within one species, as well as physiological differences between different species, may also result in different ${ }^{18} \mathrm{O} /{ }^{16} \mathrm{O}$ ratios. Moreover, below a certain water depth (ocean dependent, typically between $3-5 \mathrm{~km}$ ), the carbonate in foraminifera shells begin to dissolve (Berger, 1972). At ages older than the ${ }^{14} \mathrm{C}$ range $(50 \mathrm{ka})$ the isotope record is tied in to absolute ages by orbital tuning which can introduce maximum errors of about $5 \mathrm{ky}$ (Martinson et al., 1987). If an uncertainty range is not given in the original publication, information on the data in such detail that would allow to estimate the individual uncertainty range is often not provided either. Thus, there is a need for 
a uniform uncertainty range which takes into account all possible uncertainties named above. For the purpose of this study, we thus assume uncertainties involved with oxygen isotopes to be about $5 \mathrm{ky}$ for the period 0-50 ka, and about $10 \mathrm{ky}$ for older samples. This is a trade-off between conservative and consistent uncertainty estimation, as especially for dates younger than about $5 \mathrm{ky}$ the uncertainties can be lower.

\subsubsection{Biostratigraphy}

Biostratigraphic methods are indirect dating methods based on the identification of micro- or nanofossils in the sediment. A biozone (interval of geological strata) is assigned according to the prevailing taxons. The definitions of such biozones, the determination of statistically comparable counting techniques and the identification of fossils for biostratigraphy are often subjective, and are all potential sources of uncertainty. Additional error sources include the reworking of fossils (Sadler, 2004) and uncertainties at zone boundaries resulting from diffuse transitions between biozones (Jasko, 1984). The length of the uncertainty interval strongly depends on the frequency of individual species in the sediment and thus can vary largely between sites. Therefore, no universal error can be estimated and we use the uncertainties assigned by the original authors. One example method is the calcareous nanofossil stratigraphy introduced by Weaver (1994) which is based on the analysis of ratios of different species of coccoliths. Used in conjunction with oxygen isotope stratigraphy Weaver (1994) suggests an accuracy of a few thousand years.

\subsubsection{Uncertainties due to sample locations}

By far the largest source of uncertainty originates from the positioning of the sample in the sediment core relative to the landslide deposit or scar. Ideally, samples are taken from hemipelagic background sediment deposited after the 
event (Fig. 1a, b) to provide a minimum landslide age. For cores retrieved from the depositional zone samples may also be taken from the hemipelagic sediment deposited before the event (Fig. 1c) to provide a time bracket for the maximum landslide age. The sample is preferably taken very close to the landslide deposit or scar, whilst at the same time avoiding sediment mixing by bioturbation or bottom currents (Fig. 1g). This method is favoured by rapid sedimentation rates, and is more problematic in areas with low sedimentation rates. The time interval between deposition of the sediment from which the sample is taken and the actual event should be calculated based on local sedimentation rates and added or subtracted to the estimated age of the sample. Uncertainties arising from this interpolation can be large, especially when accumulation rates are low or unknown (Fig. 1e), but can be reduced by taking several samples to better constrain the sedimentation rate history (Fig. 1b, e).

Samples taken above the landslide scar or deposit (Fig. 1a) can give an age that is too young if the samples are located on a local high within a geometrically irregular deposit. Post-failure sedimentation on a local high in a hummocky deposit can result in a local reduction in sedimentation rate, or even a hiatus (Fig. 1f). Samples taken above the landslide deposit can also return an age older than the actual emplacement age. This occurs if the landslide deposit carries abundant microfossils that are affected by bioturbation and reworking of this deposit (Fig. 1g). On the contrary, if the landslide deposit has low carbonate content, the contamination by bioturbation is less important. It is generally best to obtain multiple dates in the sediment that drapes a landslide, such that the accumulation rate can be used to extrapolate a more precise age for the upper surface of the landslide (Fig. 1b, e). 
Samples taken below the landslide deposit (Fig. 1c) can return much older ages than the emplacement age. This is because the base of the landslide is likely to erode underlying background sediment, and the uncertainty depends on the depth of erosion.

Dating the landslide deposit itself (Fig. 1d) gives a maximum age for the failure. However, the uncertainty can be large due to reworking of the failed material, because the landslide can contain relatively old material.

Uncertainties resulting from the relative position of samples and landslide deposit in the sediment are relatively difficult to quantify. It can be reduced by extrapolating accumulation rates using multiple dates in the drape above a landslide, especially in locations with rapid sedimentation, or by having samples from many cores (e.g. Haflidason et al., 2005, for the Storegga slide). Ages that are consistent with multiple dating techniques may also be considered to be more robust.

\subsubsection{Uncertainties if landslide has multiple depositional lobes or headwalls}

Depositional lobes characterise the downslope ends of many submarine landslides (O'Leary, 1991). In some cases several lobes are mapped which could have been created successively during one event, as in the Storegga slide (Haflidason et al., 2005). However, they could have also been emplaced at longer time intervals and thus represent several separate events (Georgiopoulou et al., 2009; Förster et al., 2010). It is therefore important to take cores from all lobes in order to correctly interpret the timing of the events and to understand their temporal evolution. This is not always the case and increases the level of uncertainty. For instance, four depositional lobes are observed in the Trænadjupet slide area (Laberg et al., 2002b). Although radiocarbon ages have only been de- 
termined for one of the lobes, the slide has been interpreted as one single event (Laberg et al., 2002a,b). The same principle holds if a landslide area shows multiple headwalls. Ideally, cores need to be taken from all scars to constrain the timing between single events.

These error sources are not predictable and are therefore not included in any error estimations. Consequently, uncertainties for submarine landslide ages are always conservative.

\section{Data and methods}

A data base is established, which collates ages of submarine landslides. Except for one landslide (Walker-Massingill slide in the Gulf of Mexico), the estimated ages and/or radiocarbon dates have been published previously. We calculate actual emplacement ages from the available data and develop methods for determining uncertainty intervals for ages obtained with the ${ }^{14} \mathrm{C}$ method. The methods used to analyse the data base is explained in this section.

\subsection{Criteria for inclusion in the data set}

The data set only contains submarine landslides worldwide for which reliable ages are available. Only open continental slopes are within the scope of this paper. Volcanic island failures are omitted because they may involve subaerial material and have specific failure mechanisms (Masson et al., 2002). Only case studies in which ages were obtained by radiocarbon ${ }^{14} \mathrm{C}$ AMS measurements or by applying a combination of several methods (e.g. biostratigraphy and oxygen isotopes or bio-, magneto- and seismic stratigraphy) were accepted.

The data base also includes large turbidites with volumes $>1 \mathrm{~km}^{3}$, which increases the size of the data base significantly. Large volume turbidites in deep 
sedimentary basins have been used as proxies for landslides on the adjacent continental slope (Talling et al., 2007). Moving down the continental slope a submarine landslide may undergo progressive disintegration and can eventually turn into a density flow that is deposited several hundred kilometres away from the source (e.g. Masson et al., 2006). The 1929 Grand Banks event, where a seismically triggered landslide evolved into a turbidity current, is a seminal example (Piper and Aksu, 1987). Nevertheless, density flows can also be initiated by flood discharges from rivers (Mulder and Alexander, 2001). These flows are usually small, considering that the mean annual discharge of all rivers worldwide is $2 \cdot 10^{13} \mathrm{~kg}$ (Milliman and Syvitski, 1992), or about $11 \mathrm{~km}^{3}$, assuming a density of $1800 \mathrm{~kg} / \mathrm{m}^{3}$ (Baas and Best, 2002). Canyon levee system turbidites (e.g. Lebreiro et al., 2009; Henrich et al., 2010) are likely dominated by river input and are thus omitted here.

\subsection{Real emplacement ages}

Ages obtained from radiocarbon dating of material above (Fig. 1a, b) or below (Fig. 1c) the landslide deposits do not always provide the real emplacement date as the sample is usually taken at some distance from the failed material. Hemipelagic sedimentation rates at the location of the specific core are needed to interpolate the sample age to the age of emplacement.

The emplacement age equals radiocarbon_age $+\frac{d_{s f}}{s r}$, where $d_{s f}$ is the distance in the core between the radiocarbon sample and the failure deposit and $s r$ is the sedimentation rate. In the case of a single radiocarbon age obtained below the landslide deposit hemipelagic sedimentation rates have to be inferred elsewise, e.g. from other cores nearby or regional rates, and the emplacement age is calculated by radiocarbon_age $-\frac{d_{s f}}{s r}$. All radiocarbon ages are calendar dates after calibration with Marine09 (Reimer et al., 2009) and delta-R=0. As 
the measurement error of the ${ }^{14} \mathrm{C}$ AMS method is small compared to the uncertainty from the location of the sample relative to the landslide deposit and potential variations in the sedimentation rate, we do not take into account the measurement error and use the mean calibrated age. The age obtained assumes no erosion during emplacement. If measurements from several cores are available and the ages are similar, then the arithmetic mean of all samples is used in order to average out uncertainties. However, in the case of considerably different ages, the oldest date for samples above the landslide and the youngest for samples below the landslide are used.

For landslide ages obtained by oxygen isotope stratigraphy it is not necessary to calculate the real emplacement age as the isotope curve ideally is a series of closely spaced measurements that interpolates ages down to the landslide deposit. In the case of biostratigraphy the assignment of real emplacement ages is generally not possible because biozones rather than absolute ages are determined.

\subsection{Uncertainty estimation for emplacement ages obtained by ${ }^{14} \mathrm{C}$}

As the technical error with the ${ }^{14} \mathrm{C}$ AMS method is small, the main uncertainty in dating submarine failures arises from estimating sedimentation rates needed to calculate real emplacement ages. Sedimentation rates are usually obtained by linear interpolation between two ${ }^{14} \mathrm{C}$ ages, i.e. dividing the distance by the age difference between these two samples, or between a ${ }^{14} \mathrm{C}$ age and the seafloor with an age of zero. Ideally, several radiocarbon ages are available in the hemipelagic sediment above the landslide deposit (Fig. 1b) as the sedimentation history can be determined with a higher resolution and changes in sedimentation rates can be detected (Fig. 1e, open circles). If these values vary significantly, the sedimentation rate from the interval closest to the failure deposit is chosen. 
If only one age above the deposit is available (Fig. 1a), a linear sedimentation rate from the seafloor to the sample must be assumed (Fig. 1e, filled circles). Consequently, both the errors for the ${ }^{14} \mathrm{C}$ measurements and an uncertainty due to simplification of sedimentation rate propagate into the final sedimentation rate that is used for the age estimate of a submarine landslide. Errors can be especially large when time and distance for the interpolation are large and sedimentation rates change within short periods (Fig. 1e). We take these uncertainties into account by assuming that sedimentation rates may vary by a factor of four. A four-fold change in hemipelagic sedimentation rate over time is frequently observed in sediment cores used in this study (Tables 1-4 and 6 in Supplement). Accordingly, if the radiocarbon sample was taken above the failure deposit, the minimum age, i.e. the lower bound of the uncertainty interval, is calculated by radiocarbon_age $+\frac{d_{s f}}{s r \cdot 4}$, and the maximum age, i.e. the upper bound of the uncertainty interval, correspondingly by radiocarbon_age $+\frac{d_{s f}}{\frac{s f}{4}}$. Hence, the longer the distance between sample and failure deposit, the longer is the uncertainty interval. Low sedimentation rates enhance this effect.

The aforementioned method is applied to case studies in which minimum radiocarbon ages were available, such that the sample was taken from above the landslide deposit. If additional maximum ages were measured either from material within or below the landslide deposit and the results provide an age younger than the maximum age determined by the method described above, the latter age is discarded and the measured age accepted. If more than one age estimate is available the maximum and minimum ages for each age estimate are calculated. The overall uncertainty interval and the emplacement age for the particular event is then obtained by taking the arithmetic mean of all samples. 


\subsection{Global sea level as proxy for global climate}

The global mean sea level is used here as an analogue of global climate and environmental changes. The sea level curve used here is based on benthic foraminifera isotopic records (mean ocean $\delta^{18} O$ ) and displayed relative to present sea level (Waelbroeck et al., 2002).

\subsection{Continental slope accumulation rates}

Accumulation rates are not only important for dating marine landslides but may also directly impact on slope stability (Stigall and Dugan, 2010). Therefore we compare the timing of submarine landslides to pre-failure sedimentation rates from the continental slopes where the landslides originate. Sedimentation rate estimates are not always available from ideal locations proximal to the headwall. Cores used to determine these rates may originate from different locations on the slope and thus record different rates of sediment input. We acknowledge the uncertainties in these estimates of accumulation rates near the landslides. However, the values show whether the margin is subject to high $(>5 \mathrm{~m} / \mathrm{ky})$, intermediate $(0.5-5 \mathrm{~m} / \mathrm{ky})$ or low $(<0.5 \mathrm{~m} / \mathrm{ky})$ sedimentation rates. Relative trends in sedimentation rates such as increases and decreases are likely to be synchronous across and are likely to affect the whole continental slope so that correlation of changes in sedimentation rates to timings of landslides within one region are still relevant.

\subsection{Data presentation and statistics}

Large and irregular uncertainty intervals along with a bias towards younger ages limit a statistical analysis of landslide ages. We therefore analyse the data set both qualitatively and by using basic statistical tests. 
The frequency distribution of the data is shown by histograms. We found that the duration of the histogram bins (e.g. $1 \mathrm{ky}, 2 \mathrm{ky}$, or $5 \mathrm{ky}$ ) is important because it may change the shape of the histogram. Histogram bins must be long enough to cater for uncertainties in the data. However, shorter bins are needed to see of landslides occur during shorter lived fluctuations in sea level. We therefore analyse histograms with a range of bin durations, which are $5 \mathrm{ky}$, $2 \mathrm{ky}$ and $1 \mathrm{ky}$.

For each bin duration, two histograms are calculated. One histogram is based on the best estimate age and ignores the uncertainty in that 'best guess' of landslide age. The second histogram is calculated by taking into account the uncertainty interval and ignoring the best estimate age. It is assumed that the probability of the landslide is evenly distributed over the uncertainty interval, regardless of the best estimate age. This process is illustrated by considering an event with an uncertainty interval ranging between 3-7 ka BP, and a bin duration of $2 \mathrm{ky}$. The landslide will be assigned as 0.25 to the $2-4 \mathrm{ka}$ bin, 0.5 to the 4-6 ka bin and 0.25 to the $6-8$ ka bin.

It is also important to test if the data set is randomly distributed through time or if it has any statistically significant peaks, clusters or trends. A model of randomness is provided by the Poisson distribution. The $\chi^{2}$ test can be used to assess the goodness of fit of the data set to the Poisson distribution (Swan and Sandilands, 1995). As a temporal process is tested, the data is split into time intervals of certain lengths (identical to histogram bins as described above) and the number of bins containing a certain number of landslides $(j=0 \ldots 10)$ is counted $\left(O_{j}\right)$. We then calculate the expected number of bins $\left(E_{j}\right)$ containing certain numbers of landslides $(j)$ according to a Poisson model with the same 
total number of events $(n)$ and histogram bins $(T$, the ratio of the total length of the data set $[\mathrm{ky}]$ and the bin size $[\mathrm{ky}]$ ) as in the landslide data set:

$$
E_{j}=T \cdot e^{\frac{-n}{T}} \cdot \frac{\left(\frac{n}{T}\right)^{j}}{j !}
$$

We thus obtain an expected number of histogram bins $\left(E_{j}\right)$ with $j=1 \ldots 10$ landslides (also termed class), which can be compared to those numbers observed in the landslide data set using the $\chi^{2}$ test. The $\chi^{2}$ test is not valid if $E_{j}$ is small. There is no general convention on the minimum $E_{j}$ in one class but a value of five is often used (Swan and Sandilands, 1995). Classes with $E_{j}<5$, can be eliminated by combining two or more classes together. The resulting number of valid classes $k$ is used in the $\chi^{2}$ test:

$$
\chi^{2}=\sum_{j=1}^{k} \frac{\left(O_{j}-E_{j}\right)^{2}}{E_{j}}
$$

As the Poisson distribution has one parameter, the number of degrees of freedom $\nu$ is given by $k-2$. If the resulting value of $\chi^{2}$ is small, the observed number of histogram bins containing $j=1 . . k$ landslides is close to the expected number. Thus, if the critical $\chi_{\text {crit }}^{2}$ value within a $5 \%$ or $10 \%$ level of significance exceeds the resulting $\chi^{2}$ then the data set resembles a Poisson distribution. The test is only conducted for histogram bin lengths of $2 \mathrm{ky}$ and $1 \mathrm{ky}$ because calculations for 5 ky bins fail the $E_{j}>=5$ criterion. Furthermore, this analysis can only be applied to a data set that is free from sampling bias.

We also visually test if peaks and clusters in the landslide frequency are significantly different to those obtained in random distributions. As a measure for abnormally high peaks we analyse the maximum number of landslides in a bin. The maximum difference in number of landslides between two neighbouring bins 
will provide information about whether these large peaks cluster within sets of high peaks, i.e. describing a trend, or if they occur as single peaks surrounded by bins containing comparatively small numbers of landslides. The number of neighbouring bins containing more than the average number of landslides in a bin is used as a measure of clustering in the data. The average numbers are calculated by dividing the number of total events by the number of histogram bins, i.e. there will be six $5 \mathrm{ky}$ bins within a $30 \mathrm{ky}$ long data set. A comparison of these characteristics to those of a randomly distributed sample allows a judgement of the significance of these different characteristics. To do so, probabilities for each characteristic are computed using 1000 sets of computer generated random numbers with the same sample size and time frame as in the original landslide data base.

\subsection{Subdivision into depositional systems}

In addition to analysing the entire data set we further investigated subgroups that are characterised by fundamental differences in their depositional environment. The reason for the subdivision is that changes in sea level and climate are likely to impact different depositional environments in different ways.

Glaciated margins are thought to be strongly influenced by climatic cycles due to the direct influence of a growing and shrinking ice sheet and a significantly higher sediment input during glacials (Owen et al., 2007; Lee, 2009). In contrast, most river deltas experience the highest sediment input during deglaciation (sea level rise) or lowstands (Covault and Graham, 2010). As rivers effectively transport terrestrial sediment (Milliman and Syvitski, 1992) this subset of river fan systems is also characterised by generally high deposition rates $(>1 \mathrm{~m} / \mathrm{ky})$.

A third subset comprises stretches of continental margins characterised by 
rather low sediment deposition rates $(<1 \mathrm{~m} / \mathrm{ky})$. This includes areas that have not been affected by ice sheet coverage, are located away from major river fan systems, or have experienced strong bottom currents that prevent sediment deposition. This subset, referred to here as 'sediment-starved continental margins' includes for instance the north-west African, the south-east Australian and US east coast margins. However, there might be an element of the river fan systems subset in this group, as rivers are dynamic systems and highly influenced by local climate in the hinterland. Although virtually no rivers are known from the Sahara today, there is strong evidence for the existence of paleorivers (e.g. Pachur and Kröpelin, 1987).

Data from the north-west African margin is also taken as a separate group. This data set is unusually extensive and contains several very large landslides mapped along the continental slope as well as turbidity currents from the same sediment-starved area.

\subsection{Limitations}

\subsubsection{Bias due to limited core penetration}

In some cases scientific drill cores provide information about old buried landslides (e.g. Maslin et al., 1998), although only few landslides haven been drilled. Therefore, the majority of submarine landslides in the data set are sampled by box, piston or gravity corers. These devices have a limited penetration depth $(<30 \mathrm{~m})$ which strongly depends on the nature and fabric of the sediment. Thus, the material obtained only covers a short time interval, especially in areas of high sedimentation rates such as in river fans. In many cases the core does not penetrate the entire failed mass, so that deeply buried landslide deposits are not sampled. Cores in turbidite systems sometimes recover several sequences of landslide deposits (Table 1 and references therein), but even then the recovery 
is limited. Table 1 summarises the age limits and maximum penetration depths for several turbidite studies. This data shows that in most cases the cores date back no further than $\sim 30 \mathrm{kaBP}$, which corresponds roughly to the onset of the Last Glacial Maximum (LGM). It is therefore not possible to evaluate the frequency of landslides which occurred before the LGM.

Due to the bias towards younger landslides, we use a cut-off age of $30 \mathrm{ka}$. We assume that landslides younger than 30 ka are in most cases unaffected by this sampling bias (Table 1). Exceptions may occur in environments with rapid deposition of coarse sediment, such as trough mouth fans, where cores rarely penetrate beyond $\sim 15$ ka (e.g. King et al., 1998; ÓCofaigh et al., 2001; Laberg et al., 2002b), contributing to a regional bias (as discussed below). Following Yokoyama et al. (2000), the 30-0 ka BP period covers parts of the last sea level fall (30-22 ka BP), the lowstand during the LGM (22-18 ka BP), the rapid sea level rise (18-6 ka BP) as well as the modern highstand (6-0 ka BP).

\subsubsection{Regional bias}

Continental slopes in the different subsets may be scientifically investigated to varying levels of detail. This can be due to difficulties in accessibility, for example in regions that are permanently covered by ice. Large parts of the Antarctic continental slope and the margins surrounding the Arctic Ocean remain unexplored. River deltas are often close to good infrastructure on land and host hydrocarbon reservoirs, so the data base for these settings may be relatively good.

\subsubsection{Short term and local climatic events}

Whereas global and local climate changes are often reconstructed to annual resolution based on ice cores, tree rings, lake varves, etc., few submarine land- 
slide has a comparable resolution. The timing of the Storegga slide coincides with a local temperature drop of $3^{\circ} \mathrm{C}$ that lasted no more than 100 years (Dawson et al., 2011). However, taking into account the uncertainty interval of the Storegga event, which is as low as 55 years (Bondevik et al., 2012), we cannot exactly determine whether the slope failed during the temperature fall, the temperature low or the subsequent temperature rise. Thus, even the age of the best dated slide in the world is not good enough to allow comparison to short term climate fluctuations. Local sea level curves can also differ significantly in magnitude (Raymo and Mitrovica, 2012) as well as in phase (Owen et al., 2007) from the global mean sea level. The analysis presented here only takes into account global sea level changes and ignores local and short term climatic fluctuations.

\section{Results}

\subsection{Landslide age data base}

The data base contains 68 landslides, the geographic locations of which are shown in Fig. 2. Table 2 lists all landslides with their minimum, maximum and most likely age rounded to the nearest ten years. A brief summary of the data on which each landslide age is based on, how uncertainty intervals were obtained for individual failures and sedimentation rates in the vicinity of the respective failure is provided in the supplement to this article.

Several landslides were rejected from the data base, although some of these were included in previous landslide age compilations (e.g. in Owen et al., 2007; Lee, 2009). The Canadian abyssal plain turbidites (Grantz et al., 1996), Afen slide (Wilson et al., 2004), Rockall bank slump (Flood et al., 1979) and north Faeroe slide complex (van Weering et al., 1998) were rejected due to inconsis- 
tent ${ }^{14} \mathrm{C}$ dates. Landslide ages inferred from sediment thickness and nearby sedimentation rates, such as for the Andøya slide (Laberg et al., 2000), Peach 2 and 3 debris flows (Holmes et al., 1998), Currituck slide (Prior et al., 1986) and Amazon shallow E debris flow (Maslin et al., 2005), were omitted as well. Some turbidite systems such as in the Ulleung basin (Lee et al., 2010) had to be excluded from the data set despite their well constrained ages as no volume estimates are available.

\subsection{Data base analysis}

The age constraints for 68 submarine landslides with volumes $>1 \mathrm{~km}^{3}$ were found suitable for subsequent analysis (Table 2, Fig. 3). The most recent slide in the data base is the Trænadjupet slide $(4.22 \mathrm{ka})$, while several turbidity currents are younger, e.g. the Grand Banks event that happened in 1929 AD. The oldest event is the Cape Blanc slide off north-west Africa (135-175 ka). Out of the total 68 landslides in the data set, 32 occurred since the LGM and 41 in the past $30 \mathrm{ka}$. The data base contains predominantly younger landslides because of the $50 \mathrm{ka}$ limit of radiocarbon dating as well as the limited availability of long cores that sample deeply buried landslide deposits. We determine the quality of the age estimate for individual landslides by taking into account the number of samples and cores as well as the methodology based on which the age was determined, the quality of the sedimentation rates and the number of existing lobes and headwalls that were sampled. In this data base two entries have a very good (Grand Banks, Storegga), two have a good (Balearic Abyssal Plain, Madeira Abyssal Plain 'a'), six have an intermediate and 58 have a low quality age control. The age range between minimum and maximum ages, i.e. the uncertainty interval, can be large (up to $61 \mathrm{ky}$ ). The average uncertainty interval for all entries in the data base is $10.4 \mathrm{ky}$, and is $3.8 \mathrm{ky}$ for those younger than 30 ka. 


\subsubsection{Visual evaluation}

We separate the sea level curve shown in Fig. 3 into five intervals: Sea level rise and highstand during termination II (136-122 ka BP), sea level fall (122$22 \mathrm{kaBP})$, sea level lowstand during the LGM (22-18 ka BP), sea level rise after the LGM (18-6 ka BP) and the modern highstand (6-0 ka BP). Taking uncertainties into account, 22 events lie fully within a period of rising sea level. Ten events can be assigned to sea level fall and five events occurred during sea level highstand. Almost half of the ages in the data set (31) have uncertainties that span over one or more sea level transitions and therefore cannot be directly attributed to a particular sea level stand. When uncertainties are ignored and the best estimate ages are used, the data set contains three entries for the $14 \mathrm{ky}$ long penultimate period of sea level rise (frequency of 0.21 failures/ky), 25 entries for the $100 \mathrm{ky}$ long period of overall falling sea level (0.25 failures/ky), six entries during the $4 \mathrm{ky}$ long LGM (1.5 failures/ky), 25 entries for the $12 \mathrm{ky}$ period of sea level rise after the LGM (2.08 failures/ky) and seven entries for the last $6 \mathrm{ky}$ (1.17 failures/ky).

Fig. 4 shows a histogram representation of the data set with a histogram bin length of $5 \mathrm{ky}$. The number of landslides older than the LGM (> $22 \mathrm{ka})$ is comparatively low and three landslides occur within a $5 \mathrm{ky}$ bin at most. As uncertainties are high for old landslides we analyse the uncertainty histogram (open bars) and find that histogram peaks coincide with sea level lowstand (140$135 \mathrm{ka}, 115-105 \mathrm{ka} \mathrm{BP})$, highstand (125-120 ka, 45-35 ka BP) or rising sea level (85-80 ka, 65-60 kaBP). For the past $30 \mathrm{ka}$ uncertainties are generally smaller and the analysis is based on the histogram using best estimate ages. The histogram is nearly bell-shaped with a maximum of ten events within a single $5 \mathrm{ky}$ bin during the maximum rate of sea level rise. During the preceding sea level 
lowstand as well as the following modern highstand less failures occurred.

Figs. $5 \mathrm{a}$ and $5 \mathrm{~b}$ represent the same data base with smaller histogram bin lengths of $2 \mathrm{ky}$ and $1 \mathrm{ky}$, respectively. This representation is particularly useful for the past $\sim 30 \mathrm{ka}$ as the data base is more comprehensive, age errors are smaller and the sea level changed rapidly. A quiet period in terms of landslide occurrence can be identified when sea level rise comes to a halt with only four landslides during 6-1 ka BP. The bell-shaped curve covering a large part of the period of sea level rise since the LGM seen in Fig. 4 appears not as a curve with one maximum but rather with two maxima during early sea level rise (18-16 ka BP) and when sea level rise was in full progress (11-9 ka BP). During the early stages of the LGM (22-20 ka BP) a comparatively high number of five landslides occurred, followed by a drop to only one landslide in the $20-18$ ka interval.

\subsubsection{Statistical analysis of non-biased data $(0-30 \mathrm{kaBP})$}

The part of the data base covering the past $30 \mathrm{ka}$ is assumed free of sampling bias (see section 2.8.1). The 30-0 ka BP period comprises 40 events. Because no bias is involved, at least in terms of core depth penetration, this subset can undergo statistical tests.

The data set's fit to a Poisson model is tested using a $\chi^{2}$ test. The Poisson model describes a frequency distribution of random data. The $H_{0}$ hypothesis states that the landslides in the data set fit the Poisson model and thus are randomly distributed through time, which is accepted when the calculated value for $\chi^{2}$ is smaller than the critical $\chi^{2}$ value. The number of histogram bins that contain 0 to 10 landslides are counted (grey lines in Fig. 5c) and compared to the number of expected bins for a Poisson distributed sample (black lines in 
Fig. 5c). This is done for bin lengths of 1 and $2 \mathrm{ky}$. The $1 \mathrm{ky}$ binned landslide data (dashed lines in Fig. 5c), in particular, is in good agreement with the artificial data, which follows the Poisson distribution $\left(R^{2}=0.98\right)$. The $2 \mathrm{ky}$ bin landslide data has more spikes than the smoother artificial sample $\left(R^{2}=0.32\right)$. The $\chi^{2}$ test returns values of 0.951 and 0.043 for $2 \mathrm{ky}$ and $1 \mathrm{ky}$ binned landslide data, respectively. These are well below the critical value of 5.991 (5\% significance with two degrees of freedom). Increasing the level of significance to $10 \%$ yields a critical value of 4.605. Even with such a high level of significance, the critical values exceed the calculated $\chi^{2}$. Therefore, the $H_{0}$ hypothesis is accepted and the timing of landslides resembles a Poisson distribution, i.e. the occurrences of landslides over time are very similar to randomly distributed data.

Fig. 6 shows the probability for the maximum numbers of landslides that can occur within one histogram bin (Fig. 6a, d, g), the maximum difference in numbers of landslides between two neighbouring bins (Fig. 6b, e, h) and the number of neighbouring bins containing more than seven (Fig.6c), four (Fig.6f) and three (Fig. 6i) events in randomly distributed samples in bins of 5 ky (Fig. 6a-c), 2 ky (Fig. 6d-f) and 1 ky (Fig. 6g-i). The arrows mark the position of the landslide data set. The maximum number of landslides in the data base agrees very well with the maximum number of events that are likely to occur in random distributions (Fig. 6a, d, g). The maximum difference in the numbers of landslides between neighbouring histogram bins in the data set also conforms with those expected in random distributions (Fig. $6 \mathrm{~b}, \mathrm{e}, \mathrm{h}$ ). Therefore, the height of peaks in the original data set is not significant. Their appearance in clusters or single peaks could also originate from a random distribution. Only the number of neighbouring bins containing more than average landslides in the landslide data set exceeds the most likely number by one in the $5 \mathrm{ky}$ and $2 \mathrm{ky}$ binned 
histograms (Fig. 6c, f). However, the probability of these higher values is still larger than $10 \%$ and the occurrence is comparatively likely.

In summary, the temporal distribution of landslides resembles a Poisson distribution and is relatively easily reproduced by a random number generator. Therefore, any observed peaks and clusters as identified from Fig. 4 are not statistically significant.

\subsubsection{Timing of failures in different depositional systems}

Fig. 7 shows histograms of the data set divided into three sets of different sedimentation environments (Fig. 7a-c) as well as one regional subset (Fig. 7d) representing slides off the north-west African coast. The histogram bin length is $5 \mathrm{ky}$ in all plots.

Out of the total 68 landslides 15 occurred at glaciated continental margins (Fig. 7a). The single events are nearly evenly scattered from 140 ka BP to recent without any periods of significantly increased landslide frequency or outstanding peaks. This is evident in both the histogram based on best estimate ages and the histogram that includes uncertainties. Landsliding seemed to have occurred during all sea level conditions.

The relationship between landslide frequency and sea level is different for landslides in river fans and systems with large sedimentary input (Fig. 7b). The 36 events in this group span over a period from $115 \mathrm{ka}$ BP to recent, although only four events are older than 45 ka. The highest abundance of nine landslides was between 10-5 ka BP coinciding with a high rate of sea level rise. This peak was preceded by a gradual increase in abundance from one landslide between 30-25 ka BP during falling sea level, to nine landslides during sea level lowstand 
(25-15 ka BP). The 10-5 ka BP maximum is followed by a steep drop to only three landslides in the past $5 \mathrm{ka}$. These features are nearly identical when uncertainties are included (open bars). However, in a $2 \mathrm{ky}$ bin size representation (Fig. 8a) the outstanding peak reduces to three neighbouring moderate peaks and is even less pronounced in a 1 ky bin size histogram (Fig. 8b).

Fig. 7c shows a histogram of landslides at sediment-starved margins with comparatively little terrestrial sediment input, i.e. at moderate to low latitudes and away from rivers. This group includes failures at the north-west African continental margin, although these are also represented individually in Fig. 7d. The histogram shows a scattered distribution of nine events between 155-25 ka BP. Eight landslides are younger than 25 ka giving a slightly denser histogram distribution with seven landslides clustering at sea level lowstand and early rise during and just after the LGM (25-10 ka BP). Only one landslide is younger than 10 ka.

The landslide record on the north-west African continental margin (Fig. 7d) resembles the glaciated margin subset. All 11 data points are nearly evenly distributed over the entire time frame without any clustering or increased frequency.

For the largest of these subgroups, the river fan system group, we apply the same test for Poisson distribution as applied to the undivided data. The result is shown in Fig. 8c with the same notation as in Fig. 5c. The curves for expected and observed intervals resemble each other $\left(R^{2}=0.69\right.$ for the $2 \mathrm{ky}$ fit, $R^{2}=0.93$ for the $1 \mathrm{ky}$ fit). The $\chi^{2}$ test for 2 and $1 \mathrm{ky}$ bins returns values of 0.955 and 0.492, respectively. Both values are well below the critical 5.991 with $5 \%$ signif- 
icance with two degrees of freedom. The calculated $\chi^{2}$ values are also below the critical values with $10 \%$ significance (4.605). As with the uncategorised 0-30 ka data set, the river fan systems subset follows a Poisson process and could be essentially random.

The river system subset's peaks and cluster identified in Fig. 7b were analysed in the same way as for the main data set and the results are displayed in Fig. 9, following the notation used for Fig. 6. Independent of the bin size all characteristics of the landslide data set locate at comparatively high probabilities. Accordingly, peaks and clusters are not significant and can easily be reproduced by random numbers.

\subsubsection{Temporal variations of accumulation rates and the timing of landslides}

Fig. 10 shows the timing of submarine landslides and typical accumulation rates in their source areas, for those sites where changes in accumulation rates have been documented (Table 3). For simplification and consistency the landslide names are given rather than the name of the source area, i.e. for the slide named BIG95 sedimentation rates typical for the Ebro margin in the western Mediterranean Sea are documented. For a clearer visualisation the figure is separated into six subplots. Note the logarithmic y-scale in Fig. 10a.

Peak accumulation rates were highest in the Storegga slide area $(36 \mathrm{~m} / \mathrm{ky})$, followed by the large river fans of the Mississippi $(12 \mathrm{~m} / \mathrm{ky})$ and Amazon $(4 \mathrm{~m} / \mathrm{ky})$. All systems in Fig. 10 show increased sediment accumulation during the LGM with the exception of the Nile, where deposition rates were low until about $14 \mathrm{ka} \mathrm{BP}$ and increase while sea level was rising. The onset of rapid deposition in the Amazon Fan at about $34 \mathrm{kaBP}$ is earlier than for the other margins. The length of high accumulation intervals differ and for depositional systems 
like the Amazon and Mississippi fans, and the Iberian, Makran and south-east Australian margin these periods extend well into the onset of deglaciation. However, as the global sea level rises to almost modern level (6 ka BP) sedimentation rates at all margins decrease significantly. Through time the sediment accumulation rates changed by up to a factor of four (Makran, BIG95, Iberian margin, Heradotus basin, south-east Australia), about an order of magnitude (Trænadjupet, Mississippi/Walker-Massingill, Balearic abyssal plain, Amazon) or even more (Storegga, Nile).

The data show that landslide occurrence is higher during or after a period of increased deposition, except for three samples (Amazon Fan and Balearic abyssal plain). The delays between the onset of high accumulation rates and actual failure vary between $<1 \mathrm{ky}$ to as long as $25 \mathrm{ky}$ (Table 4 ). The delay times summarised in Table 4 involve all the uncertainties of landslide age estimates as well as uncertainties with respect to the determination of sedimentation rates. Consequently, large errors are possible and the data should be treated with caution.

\section{Discussion}

The compiled data set of ages of submarine landslides contains 68 large landslides at continental margins worldwide, and is significantly larger than previously published data sets (Maslin et al., 2004; Owen et al., 2007; Lee, 2009; Leynaud et al., 2009). For further interpretation of the data set it is important to recall that for a large part of the data base uncertainty in ages is significant, and dating is of low quality. Nearly half of the landslides in the data base have uncertainty intervals too large to be directly assigned to a particular sea level condition. 


\subsection{Apparent bin size dependence}

Using a purely qualitative approach as was done in similar studies (e.g. Owen et al., 2007; Lee, 2009; Leynaud et al., 2009), and by choosing a sufficiently large histogram bin size ( $5 \mathrm{ky}$ ), the landslide time series seems to contain several peaks, trends and clusters when compared to the global sea level curve. However, patterns such as peaks and clusters appear rather diffuse and are less prominent when the data set is plotted with smaller histogram bin sizes (compare Figs. 4 and $5 \mathrm{a}, \mathrm{b}$ as well as Figs. $7 \mathrm{~b}$ and $8 \mathrm{a}, \mathrm{b})$. This apparent bin size dependence is cautionary and, depending on which bin size is chosen, can manipulate any visual interpretation. This should be avoided by statistically testing the data set for appropriate distributions.

\subsection{Past landslide frequency}

The highest frequency of submarine landslides in a global average was during periods of rising sea level after the LGM with an average of two failures per thousand years. The landslide frequency during the LGM and the modern high stand was 1.5 and 1.2 failures per ky, respectively. The sea level fall preceding the LGM has a landslide frequency of only 0.4 failures per ky, but is likely influenced by a sampling bias. Although the landslide frequency was highest during the period of sea level rise after the LGM, statistically testing showed that this peak of landslide frequency is not significant, and could easily be achieved with a random data set.

Dividing the data set into subsets of different depositional environments results in substantially different temporal distributions in the subset. Failures at the north-west African continental slope as well as at glaciated margins are regularly spaced over time. The latter is interesting, as it has been suggested previously that the stability of glaciated margins is heavily affected by climatic 
changes owing to the direct impact of ice sheet advances and retreats or surging of glaciers (Owen et al., 2007; Tappin, 2010) as well as catastrophic floods during glacial-interglacial transition (Piper and Normark, 2009). The frequency of landslides at sediment-starved margins increases slightly towards the end of the LGM. Failures at river fan systems cluster in the past $30 \mathrm{ka}$ which is most likely an artifact of sampling bias considering high sedimentation rates usually involved in river dominated systems. The landslide frequency was highest during sea level rise (1.4 failures per ky), intermediate during the LGM and the modern high stand (1 and 0.7 failures per ky, respectively) and comparatively low during times of falling sea level ( 0.4 failures per ky). The landslide frequency of the river subset during the past $30 \mathrm{ka}$ is remarkably similar to that of the entire data set. It is thus evident that the river-subgroup dominates the overall data set. As for the uncategorised data, the peak in landslide frequency during sea level rise following the LGM is not statistically significant.

\subsection{How strong is sea level forcing of landslide frequency?}

The data set is very similar to randomly distributed artificial data. Our results show that landslide timings are distributed according to a Poisson distribution, i.e. could be essentially random, and do not show any significant trends, peaks or clusters. No statistically significant peaks can be found when splitting up the data set into groups of distinct depositional environments, even for river fed systems that appear to have more slides during low and rising sea level through visual inspection. These results stand in contrast to the conclusions of previous studies on the timing of submarine landslides by Maslin et al. (2004), Owen et al. (2007) and Lee (2009), who all suggest that the dominant factor for the timing of landslides is glacial-interglacial cyclicity.

Four factors can be responsible for the timing of landslides being random: 
(I) There is no forcing such as sea level or climate change that controls the timing of submarine landslides.

(II) The forcing is weak and the data base is too small to resolve the signal. As opposed to a strong forcing, a weak forcing requires a large data set to show up as a significant signal.

(III) Affects of sea level or climate change on slope stability are not uniform and every margin responds differently, resulting in inconsistent signals.

(IV) The landslide ages are not sufficiently accurate or are incorrect - as Storegga's age once was.

If climate does not have any influence on slope stability, or if the forcing is weak, climate-independent processes must be dominant factors causing submarine landslides. Seismicity can be assumed independent of climate. Earthquakes as triggers would likely produce randomly distributed events in a global data set. An exception are glaciated regions, where seismicity is also a function of isostatic rebound and is highest when ice sheets retreat and sea level is rising (Bungum et al., 2005). The potential of earthquakes to cause landslides is evident from field observations (Piper and Aksu, 1987) and lab testing (Biscontin et al., 2004). However, not every earthquake causes slope failures, regardless of their magnitude (Sumner et al., 2013; Völker et al., 2011). The majority of landslides in the data base originate from passive continental margins with generally low levels of seismicity. We therefore suggest that earthquakes may invoke or initiate slope instability, but are possibly not the unique mechanism for many large submarine landslides.

Oversteepening due to salt doming or other tectonic activities as well as a stress-related collapse of mechanically weak layers are other climate-independent failure mechanism. Contourite deposits forming mechanically weak layers have 
been repeatedly discussed as failure mechanisms, especially for but not limited to failures at glaciated margins (e.g. Lindberg et al., 2004; Bryn et al., 2005; Laberg and Camerlenghi, 2008).

Separate analyses for individual margins can help in explaining if and how climate affects regional or local slope stability. We attempted this for the northwest African continental margin. Unfortunately, the data is sparse and only ages for 11 landslides along an entire margin within a period of $150 \mathrm{ka}$ are available. However, visually the data set does suggest a random distribution.

\subsection{The origin of reduced landslide frequency during the modern sea level high-} stand

A prominent pattern in the data base is that significantly fewer events occur in the past $6 \mathrm{ka}$ (seven events) than during the sea level rise since the LGM (25 events). The $6-1 \mathrm{kaBP}$ period is particularly quiet with only four failures. This observation is certainly robust, as any bias due to core lengths would tend to increase the number of younger events. Global sea level was at a similar level towards the end of Termination II (125-120 ka BP), but as these old ages involve large uncertainty intervals and the data base is generally sparse this cannot be used as an analogue for the modern sea level highstand. During sea level highstand shelves are flooded and disconnected from rivers so that less sediment reaches the slopes. The level of post-glacial seismicity decreases and the stress conditions in the sediment equilibrate. Continental slopes are thus expected to stabilise during a high but stable sea level. Mechanisms causing landslides under these conditions are likely independent of sea level. Indeed, two of the three failures between 6-1 ka BP occurred at the Iberian margin (turbidites E5 and E6) and Masson et al. (2011) present evidence that earthquakes triggered the corresponding landslides. The Trænadjupet slide off the Norwegian continental 
margin is the third failure in this otherwise quiet period. Laberg et al. (2003) suggest that a contourite underlying the Trænadjupet slide acted as a mechanically weak layer. With this evidence for earthquakes and weak layers, we suggest that during stable and high sea level potential failure mechanisms are limited to those independent of sea level and therefore less failures may be expected. If over all climatic stages only climate independent failure mechanisms act, the data would be distributed uniformly and such a drop in frequency as observed during the modern highstand would not exist. This supports reasons (II) and (III) discussed above, i.e. that climate forcing may be weak and variable across different margin settings.

\subsection{Relevance of preconditioning}

Sedimentation rates at most continental margins are highest during the LGM or shortly after (Fig. 10) and thus are tightly linked to global sea level. As we do not observe a significant correlation of landslide timings with global climate or sea level, rapid sedimentation rates do not seem to be important as a direct cause for slope failure. However, an indirect impact on the stability of continental slopes is possible. Excess pore pressure develop as a result of rapid loading which decrease the strength and 'precondition' the slope for failure (e.g. Stigall and Dugan, 2010). An external trigger, most likely a climate-independent one such as an earthquake may then be necessary to eventually cause failure. Hence, although preconditioned by a climate-controlled process, the landslide can occur at any time irrespective of sea level.

Rapid deposition may allow for, accommodate, or enhance other processes capable of destabilising a slope, such as fluid flow to areas of less rapid deposition where the corresponding effective stress reduction is more critical (Dugan and Flemings, 2000; Bryn et al., 2005; Leynaud et al., 2007). A delay time is 
necessary for the fluid migration to take place which mainly depends on the permeability of the sediment as well as the distance the fluid has to travel, and may involve several thousand to a million years (Dugan and Flemings, 2000; Dugan, 2012). This may explain the observed variations in delay times between the onset of rapid deposition and the timing of the failure (Table 4) and supports reason (III) discussed above. 2D numerical modelling of excess pore pressure generation due to fluid flow for well-constrained case studies as for the Storegga slide (Leynaud et al., 2007) and the New Jersey continental margin (Dugan and Flemings, 2000) can help to test this hypothesis.

\subsection{Future geohazard from submarine landslides}

Our work suggests that, at least during the last $30 \mathrm{ka}$, there has not been a strong global linkage between the frequency of major $\left(>1 \mathrm{~km}^{3}\right)$ landslides and rapid sea level rise. The linkage is sufficiently weak that it is not statistically significant in our data set. This suggests that future rises in sea level will not make a significant difference to global landslide frequency. However, we acknowledge that the data set has uncertainties and has a limited number of examples. It is also possible that local signals are masked in a global data set, and by comparing it to eustatic sea level. For geohazard evaluation on a regional scale further studies are needed that assess the landslide frequency in specific regions in response to local sea level changes. These could be glaciated margins, where local sea level patterns can be inherently different to the global trend (Peltier, 2002), or river fan systems with different peak deposition timings (Covault and Graham, 2010). 


\section{Conclusions}

A data set with ages of 68 submarine landslides at open continental slopes with volumes $>1 \mathrm{~km}^{3}$ has been compiled. This data base is the most comprehensive one to date and is the only one considering uncertainty intervals to the age estimates, and to include changes in local sedimentation rates.

Based on this data set we do not find statistical evidence for a climate control on the timing of large submarine landslides, as these resemble a Poisson distribution in which events are essentially random. One reason could be that the sample size is too small and/or the forcing too weak to be statistically significant. Another explanation is that the impact of climate on factors promoting slope instability is not uniform and margins respond differently to an external climate forcing, thus resulting in an inconsistent signal. For example fluid flow within the slope may act as an important factor controlling the timing of failure. However, there does not appear to be a very strong linkage between sea level and landslide frequency.

A time lag of several kiloyears between periods of rapid deposition and slope failure implies that in most cases rapid deposition does not immediately trigger failure. Rapid deposition may well weaken the slope due to excess pore pressures locked in low permeable sediment, or due to fluid migration within layers of high permeability towards areas far away from the excess pore pressure initiation area.

About half of the landslides in the data base have uncertainties that are too large to attribute them to a particular sea level stand. To confidently reject or confirm any climate dependence an unbiased data set that covers one full sea 


\section{Acknowledgements}

We would like to thank Jason Chaytor and Stein Bondevik for their thoughtful reviews, which helped to significantly improve this paper. James Hunt kindly provided the Agadir basin stratigraphy. Matthew Owen is thanked for providing detailed information on the Peach 4 debrite. 


\section{References}

Baas, J. H., Best, J. L., 2002. Turbulence modulation in clay-rich sediment-laden flows and some implications for sediment deposition. Journal of Sedimentary Research 72 (3), 336-340.

Baas, J. H., Mienert, J., Abrantes, F., Prins, M. A., 1997. Late Quaternary sedimentation on the Portuguese continental margin: climate-related processes and products. Paleogeography, Paleoclimatology, Paleoecology 130, 1-23.

Balsam, W., 1981. Late Quaternary sedimentation in the western north Atlantic: stratigraphy and paleoceanography. Palaeogeography, Palaeoclimatology, Palaeoecology 35 (0), $215-240$.

Berger, W. H., Apr. 1972. Deep sea carbonates: Dissolution facies and age-depth constancy. Nature 236 (5347), 392-395.

Berger, W. H., Wefer, G., 1991. Productivity of the glacial ocean: Discussion of the iron hypothesis. Limnology and Oceanography 36 (8), 1899-1918.

Biscontin, G., Pestana, J. M., Nadim, F., 2004. Seismic triggering of submarine slides in soft cohesive soil deposits. Marine Geology 203, 341-354.

Bondevik, S., Stormo, S. K., Skjerdal, G., 2012. Green mosses date the Storegga tsunami to the chilliest decades of the 8.2 ka cold event. Quaternary Science Reviews $45(0), 1-6$.

Bourget, J., Zaragosi, S., Ellouz-Zimmermann, N., Mouchot, N., Garlan, T., Schneider, J.-L., Lanfumey, V., Lallemant, S., 2011. Turbidite system architecture and sedimentary processes along topographyically complex slopes: the Makran convergent margin. Sedimentology 58, 376-406. 
Bourget, J., Zaragosi, S., Rodriguez, M., Fournier, M., Garlan, T., ChamotRooke, N., 2013. Late Quaternary megaturbidites of the Indus Fan: Origin and stratigraphic significance. Marine Geology 336, 10-23.

Boyd, R., Keene, J., Hubble, T., Gardner, J., Glenn, K., Ruming, K., Exon, N., 2010. Southeast Australia: A Cenozoic continental margin dominated by mass transport. In: Mosher, D. C., Shipp, R. C., Moscardelli, L., Chaytor, J. D., Baxter, C. D. P., Lee, H. J., Urgeles., R. (Eds.), Submarine Mass Movements and Their Consequences. Vol. 28 of Advances in Natural and Technological Hazards Research. Springer Netherlands, pp. 491-502.

Bozzano, G., Kuhlmann, H., Alonso, B., 2002. Storminess control over African dust input to the Moroccan Atlantic margin (NW Africa) at the time of maxima boreal summer insolation: a record of the last 220 kyr. Palaeogeography, Palaeoclimatology, Palaeoecology 183 (1-2), 155-168.

Bryn, P., Berg, K., Forsberg, C. F., Solheim, A., Kvalstad, T. J., 2005. Explaining the Storegga Slide. Marine and Petroleum Geology 22 (1-2), 11-19.

Bugge, T., Belderson, R. H., Kenyon, N. H., 1988. The Storegga Slide. Philosophical Transactions of the Royal Society 325, 357-388.

Bungum, H., Lindholm, C., Faleide, J., 2005. Postglacial seismicity offshore midNorway with emphasis on spatio-temporal-magnitudal variations. Marine and Petroleum Geology 22 (1-2), 137-148.

Canals, M., Lastras, G., Urgeles, R., Casamor, J. L., Mienert, J., Cattaneo, A., Batist, M. D., Haflidason, H., Imbo, Y., Laberg, J. S., Locat, J., Long, D., Longva, O., Masson, D. G., Sultan, N., Trincardi, F., Bryn, P., 2004. Slope failure dynamics and impacts from seafloor and shallow sub-seafloor geophysical data: case studies from the COSTA project. Marine Geology 213, 9-72. 
Castelltort, S., VanDenDriessche, J., 2003. How plausible are high-frequency sediment supply-driven cycles in the stratigraphic record? Sedimentary Geology $157(1-2), 3-13$.

Clark, P. U., Dyke, A. S., Shakun, J. D., Carlson, A. E., Clark, J., Wohlfarth, B., Mitrovica, J. X., Hostetler, S. W., McCabe, A. M., 2009. The Last Glacial Maximum. Science 325, 710-714.

Clarke, S., Hubble, T., Airey, D., Yu, P., Boyd, R., Keene, J., Exon, N., Gardner, J., 2012. Submarine landslides on the upper Southeast Australian passive continental margin - preliminary findings. In: Yamada, Y., Kawamura, K., Ikehara, K., Ogawa, Y., Urgeles, R., Mosher, D., Chaytor, J., Strasser, M. (Eds.), Submarine Mass Movements and Their Consequences. Vol. 31 of Advances in Natural and Technological Hazards Research. Springer Netherlands, pp. 55-66.

Coleman, J. M., Prior, D. B., 1988. Mass wasting on continental margins. Annual Reviews of Earth and Planetary Science 16, 101-119.

Covault, J. A., Graham, S. A., 2010. Submarine fans at all sea-level stands: Tectono-morphologic and climatic controls on terrigenous sediment delivery to the deep sea. Geology 38 (10), 939-942.

Dahlgren, K., Vorren, T. O., 2003. Sedimentary environment and glacial history during the last 40 ka of the Vøring continental margin, mid-Norway. Marine Geology 193 (1-2), 93-127.

Dawson, A., Bondevik, S., Teller, J. T., 2011. Relative timing of the Storegga submarine slide, methane release, and climate change during the 8.2 ka cold event. The Holocene 21 (7), 1167-1171.

DeFoor, W., Person, M., Larsen, H. C., Lizarralde, D., Cohen, D., Dugan, 
B., 2011. Ice sheet-derived submarine groundwater discharge on Greenland's continental shelf. Water Resources Research 47.

Dennielou, B., Jallet, L., Sultan, N., Jouet, G., Giresse, P., Voisset, M., Berne, S., 2009. Post-glacial persistence of turbiditic activity within the Rhone deepsea turbidite system (Gulf of Lions, Western Mediterranean): Linking the outer shelf and the basin sedimentary records. Marine Geology 257, 65-86.

Dowdeswell, J. A., Elverhøi, A., 2002. The timing of initiation of fast-flowing ice streams during a glacial cycle inferred from glacimarine sedimentation. Marine Geology 188 (1-2), 3-14.

Ducassou, E., Capotondi, L., Murat, A., Bernasconi, S. M., Mulder, T., Gonthier, E., Migeon, S., Duprat, J., Gireaudeau, J., Mascle, J., 2007. Multiproxy Late Quaternary stratigraphy of the Nile deep-sea turbidite system Towards a chronology of deep-sea terrigeneous systems. Sedimentary Geology $200,1-13$.

Ducassou, E., Migeon, S., Mulder, T., Murat, A., Capotondi, L., Bernasconi, S. M., Mascle, J., 2009. Evolution of the Nile deep-sea turbidite system during the Late Quaternary: influence of climate change on fan sedimentation. Sedimentology 56, 2061-2090.

Dugan, B., 2012. A review of overpressure, flow focusing, and slope failure. In: Yamada, Y., Kawamura, K., Ikehara, K., Ogawa, Y., Urgeles, R., Mosher, D., Chaytor, J., Strasser, M. (Eds.), Submarine Mass Movements and Their Consequences. Vol. 31 of Advances in Natural and Technological Hazards Research. Springer Netherlands, pp. 267-276.

Dugan, B., Flemings, P. B., 2000. Overpressure and fluid flow in the New Jersey continental slope: Implications for slope failure and cold seeps. Science 289, $288-291$. 
Elmore, R. D., Pilkey, O. H., Cleary, W. J., Curran, H. A., 1979. Black Shell turbidite, Hatteras Abyssal Plain, western Atlantic Ocean. Geological Society of America Bulletin 90, 1165-1176.

Evans, D., Harrison, Z., Shannon, P. M., Laberg, J. S., Nielsen, T., Ayers, S., Holmes, R., Hoult, R. J., Lindberg, B., Haflidason, H., Long, D., Kuijpers, A., Andersen, E. S., Bryn, P., 2005. Paleoslides and other mass failures of Pliocene to Pleistocene age along the Atlantic continental margin of NW Europe. Marine and Petroleum Geology 22, 1131-1148.

Flemings, P., Behrmann, J., John, C., Expedition 308 Scientists, 2006. Gulf of Mexico Hydrogeology. Proceedings of the Ocean Drilling Program, Scientific Results, Expedition 308308.

Flood, R., Hollister, C., Lonsdale, P., 1979. Disruption of the Feni sediment drift by debris flows from Rockall Bank. Marine Geology 32 (3-4), 311-334.

Förster, A., Ellis, R., Henrich, R., Krastel, S., Kopf, A. J., 2010. Geotechnical characterisation and strain analyses of sediment in the Mauritania Slide Complex, NW-Africa. Marine and Petroleum Geology 27 (6), 1175-1189.

Garziglia, S., Migeon, S., Ducassou, E., Loncke, L., Mascle, J., 2008. Masstransport deposits on the Rosetta province (NW Nile deep-sea turbidite system, Egyptian margin): Characteristics, distribution and potential causal processes. Marine Geology 250, 180-198.

Georgiopoulou, A., Masson, D. G., Wynn, R. B., Krastel, S., 2010. Sahara Slide: Age, initiation, and processes of a giant submarine slide. Geochemistry Geophysics Geosystems 11 (7).

Georgiopoulou, A., Wynn, R. B., Masson, D. G., Frenz, M., 2009. Linked 
turbidite-debrite resulting from recent Sahara Slide headwall reactivation. Marine and Petroleum Geology 26, 2021-2031.

Gracia, E., Vizcaino, A., Escutia, C., Asioli, A., Rodes, A., Pallas, R., GarciaOrellana, J., Lebreiro, S. M., Goldfinger, C., 2010. Holocene earthquake record offshore Portugal (SW Iberia): testing turbidite paleoseismology in a slow-convergence margin. Quaternary Science Reviews 29, 1156-1172.

Grantz, A., Philips, R. L., Mullen, M. W., Starratt, S. W., Jones, G. A., Naidu, A. S., Finney, B. P., 1996. Character, paleoenvironment, rate of accumulation, and evidence for seismic triggering of Holocene turbidites, Canada Abyssal Plain, Arctic Ocean. Marine Geology 133, 51-73.

Gröger, M., Henrich, R., Bickert, T., 2003. Glacial-interglacial variability in lower North Atlantic deep water: inference from silt grain-size analysis and carbonate preservation in the western equatorial Atlantic. Marine Geology $201(4), 321-332$.

Haflidason, H., Lien, R., Sejrup, H. P., Forsberg, C. F., Bryn, P., 2005. The dating and morphometry of the Storegga Slide. Marine and Petroleum Geology $22,123-136$.

Haflidason, H., Sejrup, H. P., Nygard, A., Mienert, J., Bryn, P., Lien, R., Forsberg, C. F., Berg, K., Masson, D., 2004. The Storegga Slide: architecture, geometry and slide development. Marine Geology 213, 201-234.

Hampton, M. A., Lee, H. J., Locat, J., 1996. Submarine landslides. Reviews of Geophysics 34, 33-59.

Henrich, R., Cherubini, Y., Meggers, H., 2010. Climate and sea level induced turbidite activity in a canyon system offshore the hyperarid Western Sahara (Mauritania): The Timiris Canyon. Marine Geology 275 (1-4), 178-198. 
Henrich, R., Hanebuth, T. J. J., Krastel, S., Neubert, N., Wynn, R. B., 2008. Architecture and sediment dynamics of the Mauritania Slide Complex. Marine and Petroleum Geology 25 (1), 17-33.

Hjelstuen, B. O., Sejrup, H. P., Haflidason, H., Nygard, A., Berstad, I. M., Knorr, G., 2004. Late Quaternary seismic stratigraphy and geological development of the south Vøring margin, Norwegian Sea. Quaternary Science Reviews 23, 1847-1865.

Holmes, R., Long, D., Dodd, L. R., 1998. Large-scale debrites and submarine landslides on the Barra Fan, west of Britain. Geological Society, London, Special Publications 129 (1), 67-79.

Hornbach, M. J., Lavier, L. L., Ruppel, C. D., 2007. Triggering mechanism and tsunamogenic potential of the Cape Fear Slide complex, U.S. Atlantic margin. Geochemistry Geophysics Geosystems 8 (12).

Hunt, J. E., 2012. Determing the provenance, recurrence, magnitudes and failure mechanisms of submarine landslides from the Moroccan Margin and Canary Islands using distal turbidite records. Ph.D. thesis, Faculty of Natural and Environmental Sciences, School of Ocean and Earth Sciences, University of Southampton.

Huppertz, T. J., Piper, D. J. W., 2009. The influence of shelf-crossing glaciation on continental slope sedimentation, Flemish Pass, eastern Canadian continental margin. Marine Geology 26, 67-85.

Hutson, W. H., 1980. Bioturbation of deep-sea sediments: Oxygen isotopes and stratigraphic uncertainty. Geology 8, 127-130.

Imbrie, J., Hays, J. D., Martinson, D. G., McIntyre, A., Mix, A. C., Morley, J. J., Pisias, N. G., Prell, W. L., Shackleton, N. J., 1984. The orbital the- 
ory of Pleistocene climate : support from a revised chronology of the marine $\delta^{18}$ O record. In: Berger, A., Imbrie, J., Hays, J., Kukla, G., Saltzman, B. (Eds.), Milankovitch and Climate: Understanding the Response to Astronomical Forcing. p. 269.

Jasko, T., 1984. The first find: estimation of the precision of range zone boundaries. Computers \& Geosciences 10 (1), 133-136.

Jenkins, C. J., Keene, J. B., 1992. Submarine slope failures of the southeast Australian continental slope: a thinly sedimented margin. Deep-Sea Research $39(2), 121-136$.

King, E., Haflidason, H., Sejrup, H., Løvlie, R., 1998. Glacigenic debris flows on the North Sea Trough Mouth Fan during ice stream maxima. Marine Geology $152(1-3), 217-246$.

Knutz, P., Jones, E., Austin, W., van Weering, T., 2002. Glacimarine slope sedimentation, contourite drifts and bottom current pathways on the Barra Fan, UK North Atlantic margin. Marine Geology 188 (1-2), 129 - 146.

Kolla, V., Perlmutter, M. A., 1993. Timing of turbidite sedimentation on the Mississippi Fan. AAPG Bulletin 77 (7), 1129-1141.

Kroon, D., Shimmield, G., Austin, W. E. N., Derrick, S., Knutz, P., Shimmield, T., 2000. Century- to millennial-scale sedimentological-geochemical records of glacial-Holocene sediment variations from the Barra Fan (NE Atlantic). Journal of the Geological Society, London 157, 643-653.

Kvenvolden, K. A., 1993. Gas hydrates-geological perspective and global change. Reviews of Geophysics 31 (2), 173-187.

Laberg, J., Vorren, T., Dowdeswell, J., Kenyon, N., Taylor, J., 2000. The 
Andøya Slide and the Andøya Canyon, north-eastern Norwegian-Greenland Sea. Marine Geology 162 (2-4), 259-275.

Laberg, J., Vorren, T., Kenyon, N., Ivanov, M., 2006. Frequency and triggering mechanisms of submarine landslides of the North Norwegian continental margin. Norwegian Journal of Geology 86, 155-161.

Laberg, J., Vorren, T., Mienert, J., Bryn, P., Lien, R., 2002a. The Trænadjupet Slide: a large slope failure affecting the continental margin of Norway 4,000 years ago. Geo-Marine Letters 22, 19-24.

Laberg, J. S., Camerlenghi, A., 2008. The significance of contourites for submarine slope stability. In: Developments in Sedimentology. Vol. 60. pp. 537-556.

Laberg, J. S., Dahlgren, T., Vorren, T. O., Haflidason, H., Bryn, P., 2001. Seismic analyses of Cenozoic contourite drift development in the Northern Norwegian Sea. Marine Geophysical Researches 22, 401-416.

Laberg, J. S., Vorren, T. O., Mienert, J., Evans, D., Lindberg, B., Ottesen, D., Kenyon, N. H., Henriksen, S., 2002b. Late Quaternary paleoenvironment and chronology in the Trænadjupet Slide area offshore Norway. Marine Geology $188,35-60$.

Laberg, J. S., Vorren, T. O., Mienert, J., Haflidason, H., Bryn, P., Lien, R., 2003. Preconditions leading to the Holocene Trænadjupet Slide offshore Norway. In: Locat, J., Mienert, J., Boisvert, L. (Eds.), Submarine Mass Movements and Their Consequences. Vol. 19 of Advances in Natural and Technological Hazards Research. Springer Netherlands, pp. 247-254.

Lassey, K. R., Manning, M. R., Sparks, R. J., Wallace, G., 1990. Radiocarbon in the sub- tropical convergence east of Tasmania- an interim report. Tech. rep., DSIR Physical Sciences. 
Lastras, G., Canals, M., Hughes-Clarke, J. E., Moreno, A., Batist, M. D., Masson, D. G., Cochonat, P., 2002. Seafloor imagery from the BIG'95 debris flow, western Mediterranean. Geology 30 (10), 871-874.

Lastras, G., Canals, M., Urgeles, R., Batist, M. D., 2004. Characterisation of the recent BIG'95 debris flow deposit on the Ebro margin, Western Mediterranean Sea, after a variety of seismic reflection data. Marine Geology 213, 235-255.

Lebreiro, S. M., Voelker, A. H. L., Vizcaino, A., Abrantes, F. G., Alt-Epping, U., Jung, S., Thouveny, N., Gracia, E., 2009. Sediment instability on the Portuguese continental margin under abrupt glacial climate changes (last 60 kyr). Quaternary Science Reviews 28, 3211-3223.

Lee, H. J., 2009. Timing and occurrence of large submarine landslides on the Atlantic Ocean Margin. Marine Geology 264, 53-64.

Lee, H. J., Chough, S. K., Yoon, S. H., 1996. Slope-stability change from late Pleistocene to Holocene in the Ulleung Basin, East Sea (Japan Sea). Sedimentary Geology 104, 39-51.

Lee, S. H., Bahk, J. J., Kim, H. J., Lee, K. E., Jou, H. T., Suk, B. C., 2010. Changes in the frequency, scale, and failing areas of latest Quaternary (i29.4 cal. ka B.P.) slope failures along the SW Ulleung Basin, East Sea (Japan Sea), inferred from depositional characters of densely dated turbidite successions. Geo-Marine Letters 30, 133-142.

Leynaud, D., Mienert, J., Vanneste, M., 2009. Submarine mass movements on glaciated and non-glaciated European continental margins: A review of triggering mechanisms and preconditions to failure. Marine and Petroleum Geology $26,618-632$.

Leynaud, D., Sultan, N., Mienert, J., 2007. The role of sedimentation rate 
and permeability in the slope stability of the formerly glaciated Norwegian continental margin: the Storegga Slide model. Landslides 4, 297-309.

Lindberg, B., Laberg, J. S., Vorren, T. O., 2004. The Nyk Slide - morphology, progression, and age of a partly buried submarine slide offshore northern Norway. Marine Geology 213, 277-289.

Lisiecki, L. E., Raymo, M. E., Jan. 2005. A Pliocene-Pleistocene stack of 57 globally distributed benthic $\delta^{18} O$ records. Paleoceanography 20 (1), PA10031010.

Liu, X., Flemings, P. B., 2009. Dynamic response of oceanic hydrates to sea level drop. Geophysical Research Letters 36.

Locat, J., Lee, H. J., 2002. Submarine landslides: advances and challenges. Canadian Geotechnical Journal 39, 193-212.

Martinson, D. G., Pisias, N. G., Hays, J. D., Imbrie, J., Theodore C Moore, J., Shackleton, N., 1987. Age dating and the orbital theory of the ice ages: development of a high-resolution 0 to 300,000-year chronostratigraphy. Quaternary Research 27, 1-29.

Maslin, M., Mikkelsen, N., Vilela, C., Haq, B., 1998. Sea-level- and gas-hydratecontrolled catastrophic sediment failures of the Amazon Fan. Geology 26 (12), $1107-1110$.

Maslin, M., Owen, M., Day, S., Long, D., 2004. Linking continental-slope failures and climate change: Testing the clathrate gun hypothesis. Geology 32, 53-56.

Maslin, M., Vilela, C., Mikkelsen, N., Grootes, P., 2005. Causes of catastrophic sediment failures of the Amazon Fan. Quaternary Science Reviews 24, 21802193. 
Masson, D., Watts, A., Gee, M., Urgeles, R., Mitchell, N., Bas, T. L., Canals, M., 2002. Slope failures on the flanks of the western Canary Islands. EarthScience Reviews 57 (1-2), $1-35$.

Masson, D. G., Arzola, R. G., Wynn, R. B., Hunt, J. E., Weaver, P. P. E., 2011. Seismic triggering of landslides and turbidity currents offshore Portugal. Geochemistry Geophysics Geosystems 12 (12).

Masson, D. G., Harbitz, C. B., Wynn, R. B., Pedersen, G., Løvholt, F., 2006. Submarine landslides: processes, triggers and hazard prediction. Philosophical Transactions of the Royal Society 364, 2009-2039.

McCave, I. N., Manighetti, B., Robinson, S. G., 1995. Sortable silt and find sediment size/composition slicing: Parameters for paleocurrent speed and paleoceanography. Paleoceanography 10, 593-610.

Métiver, F., Gaudemer, Y., 1999. Stability of output fluxes of large rivers in South and East Asia during the last 2 million years: implications on floodplain processes. Basin Research 11 (4), 293-303.

Mikkelsen, N., Maslin, M., Giraudeau, J., Showers, W., 1997. Biostratigraphy and sedimentation rates of the Amazon Fan. In: Flood, R., Piper, D., Klaus, A., Peterson, L. (Eds.), Proceedings of the Ocean Drilling Program, Scientific Results. Vol. 155, 577-594.

Milliman, J. D., Syvitski, J. P. M., 1992. Geomorphic/tectonic control of sediment discharge to the ocean: The importance of small mountaineous rivers. The Journal of Geology 100, 525-544.

Milne, G. A., Davis, J. L., Mitrovica, J. X., Scherneck, H. G., Johansson, J. M., Vermeer, M., Koivula, H., 2001. Space-geodetic constraints on glacial isostatic adjustment in Fennoscandia. Science 291, 2381-2385. 
Mörner, N., 1979. The Fennoscandian uplift and late cenozoic geodynamics: geological evidence. GeoJournal 3 (3), 287-318.

Mulder, T., Alexander, J., 2001. The physical character of subaqueous sedimentary density flows and their deposits. Sedimentology 48 (2), 269-299.

Mulder, T., Moran, K., 1995. Relationship among submarine instabilities, sea level variations, and the presence of an ice sheet on the continental shelf: An example from the Verrill Canyon Area, Scotian Shelf. Paleoceanography $10(1), 137-154$.

Nelson, C. H., 1990. Estimated post-Messinian sediment supply and sedimentation rates on the Ebro continental margin, Spain. Marine Geology 95, 395-418.

Nittrouer, C. A., 2007. Continental marigin sedimentation - from sediment transport to sequence stratigraphy. Wiley-Blackwell.

ÓCofaigh, C., Dowdeswell, J. A., Grobe, H., 2001. Holocene glacimarine sedimentation, inner Scoresby Sund, East Greenland: the influence of fast-flowing ice-sheet outlet glaciers. Marine Geology 175 (1-4), 103 - 129.

O'Leary, D. W., 1991. Structures and morphology of submarine slab slides: clues to origin and behavior. Marine Geotechnology 10, 53-69.

Owen, M., Day, S., Long, D., 2010. Investigations on the Peach 4 Debrite, a late Pleistocene mass movement on the Northwest British Continental Margin. In: Mosher, D. C., Shipp, R. C., Moscardelli, L., Chaytor, J. D., Baxter, C. D. P., Lee, H. J., Urgeles., R. (Eds.), Submarine Mass Movements and Their Consequences. Vol. 28 of Advances in Natural and Technological Hazards Research. Springer Netherlands, pp. 301-311.

Owen, M., Day, S., Maslin, M., 2007. Late Pleistocene submarine mass movements: occurrence and causes. Quaternary Science Reviews 26, 958-978. 
Pachur, H. J., Kröpelin, S., 1987. Wadi Howar: Paleoclimatic evidence from an extinct river system in the southeastern Sahara. Science 237 (4812), 298-300.

Paull, C. K., Buelow, W. J., III, W. U., Borowski, W. S., 1996. Increased continental-margin slumping frequency during sea-level lowstands above gas hydrate-bearing sediments. Geology 24, 143-136.

Pearce, T. J., Jarvis, I., 1992. Composition and provenance of turbidite sands: Late Quaternary, Madeira Abyssal Plain. Marine Geology 109, 21-51.

Peltier, W., 2002. On eustatic sea level history: Last Glacial Maximum to Holocene. Quaternary Science Reviews 21 (1-3), 377-396.

Piper, D. J., Normark, W. R., 2009. Processes that initiate turbidity currents and their influence on turbidites: A marine geology perspective. Journal of Sedimentary Research 79 (6), 347-362.

Piper, D. J. W., Aksu, A. E., 1987. The source and origin of the 1929 Grand Banks turbidity current inferred from sediment budgets. Geo-Marine Letters 7 (4), 177-182.

Piper, D. J. W., Mosher, D. C., Gauley, B. J., Jenner, K., Campbell, D. C., 2003. The chronology and recurrence of submarine mass movements on the continental slope off southeastern canada. In: Locat, J., Mienert, J., Boisvert, L. (Eds.), Submarine Mass Movements and Their Consequences. Vol. 19 of Advances in Natural and Technological Hazards Research. Springer Netherlands, pp. 299-306.

Posamentier, H. W., Allen, G. P., James, D. P., Tesson, M., 1992. Forced regressions in a sequence stratigraphic framework; concepts, examples, and exploration significance. AAPG Bulletin 76 (11), 1687-1709. 
Prell, W. L., Imbrie, J., Martinson, D. G., Morley, J. J., Pisias, N. G., Shackleton, N. J., Streeter, H. F., 1986. Graphic correlation of oxygen isotope stratigraphy application to the Late Quaternary. Paleoceanography 1 (2), 137-162.

Prins, M. A., Postma, G., Weltje, G. J., 2000. Controls on terrigenous sediment supply to the Arabian Sea during the late Quaternary: the Makran continental slope. Marine Geology 169, 351-371.

Prior, D. B., Doyle, E. H., Neurauter, T., 1986. The Currituck Slide, midAtlantic continental slope - Revisited. Marine Geology 73 (1-2), 25-45.

Rahmstorf, S., 2002. Ocean circulation and climate during the past 120,000 years. Nature 419, 207-214.

Raymo, M. E., Mitrovica, J. X., 2012. Collapse of polar ice sheets during the stage 11 interglacial. Nature 483, 453-456.

Reagan, M. T., Moridis, G. J., 2008. Dynamic response of oceanic hydrate deposits to ocean temperature change. Journal of Geophysical Research 113.

Reeder, M. S., Rothwell, R. G., Stow, D. A. V., 2000. Influence of sea level and basin physiography on emplacement of the late Pleistocene Heradotus Basin Megaturbidite, SE Mediterranean Sea. Marine and Petroleum Geology 17, $199-218$.

Reeder, M. S., Stow, D. A. V., Rothwell, R. G., 2002. Late Quaternary turbidite input into the east Mediterranean basin: new radiocarbon constraints on climate and sea-level control. Geological Society Special Publications 191, $267-278$.

Reid, R. P., Carey, S. N., Ross, D. R., 1996. Late Quaternary sedimentation in the Lesser Antilles island arc. Geological Society of America Bulletin 108 (1), 78-100. 
Reimer, P. J., Baillie, M. G. L., Bard, E., Bayliss, A., Beck, J. W., Blackwell, P. G., Ramsey, C. B., Buck, C. E., Burr, G. S., Edwards, R. L., Friedrich, M., Grootes, P. M., Guilderson, T. P., Hajdas, I., Heaton, T. J., Hogg, A. G., Hughen, K. A., Kaiser, K. F., Kromer, B., McCormac, F. G., Manning, S. W., Reimer, R. W., Richards, D. A., Southon, J. R., Talamo, S., Turney, C. S. M., van der Plicht, J., Weyhenmeyer, C. E., 2009. Intcal09 and Marine09 radiocarbon age calibration curves, 0-50,000 years cal BP. Radiocarbon 51 (4), $1111-1150$.

Revel, M., Cremer, M., Grousset, F. E., Labeyrie, L., 1996. Grain-size and Sr Nd isotopes as tracer of paleo-bottom current strength, Northeast Atlantic Ocean. Marine Geology 131 (3-4), 233-249.

Rodriguez, N. M., Paull, C. K., 2000. 14C dating of sediment of the uppermost Cape Fear Slide plain: Constraints on the timing of this massive submarine landslide. In: Paull, C. K., Matsumoto, R., Wallace, P., Dillon, W. (Eds.), Proceedings of the Ocean Drilling Program, Scientific Results. Vol. 164, 325327.

Rørvik, K. L., Laberg, J. S., Hald, M., Ravna, E. K., Vorren, T. O., 2010. Behavior of the northwestern part of the Fennoscandian Ice Sheet during the Last Glacial Maximum - a response to external forcing. Quaternary Science Reviews 29, 2224-2237.

Rothwell, R., Thomson, J., G.Kähler, 1998. Low-sea-level emplacement of very large Late Pleistocene 'megaturbidite' in the western Mediterranean Sea. Nature $392,377-380$.

Rothwell, R. G., Reeder, M. S., Anastasakis, G., Stow, D. A. V., Thomson, J., Kähler, G., 2000. Low sea-level stand emplacement of megaturbidites in the western and eastern Mediterranean Sea. Sedimentary Geology 135, 75-88. 
Sadler, P. M., 2004. Quantitative biostratigraphy - achieving finer resolution in global correlation. Annual Reviews of Earth and Planetary Science 32, $187-213$.

Sarnthein, M., Tiedemann, R., 1989. Toward a high resolution stable isotope stratigraphy of the last 3.4 million years: Sites 658 and 659 off Northwest Africa. In: Proceedings of the Ocean Drilling Program, Scientific Results. Vol. 108, 167-184.

Shackleton, N. J., Opdyke, N. D., 1973. Oxygen isotope and paleomagnetic stratigraphy of Equatorial Pacific core V28-238: Oxygen isotope temperatures and ice volumes on a $10^{5}$ year and $10^{6}$ year scale. Quaternary Research 3, 3955.

Stigall, J., Dugan, B., 2010. Overpressure and earthquake initiated slope failure in the Ursa region, northern Gulf of Mexico. Journal of Geophysical Research 115 (B04101).

Sumner, E., Siti, M. I., McNeill, L., Talling, P. J., Henstock, T. J., Wynn, R. B., Djajadihardja, Y., Permana, H., 2013. Can turbidites be used to reconstruct a palaeoearthquake record for the central Sumatran margin? Geology (in press).

Suter, J. R., Berryhill, H. L., 1985. Late Quaternary shelf-margin deltas, Northwest Gulf of Mexico. AAPG Bulletin 69 (1), 77-91.

Swan, A. R. H., Sandilands, M., 1995. Introduction to geological data analysis. Blackwell Science Ltd.

Talling, P. J., Wynn, R. B., Masson, D. G., Frenz, M., Cronin, B. T., Schiebel, R., Akhmetzhanov, A. M., Dallmeier-Tiessen, S., Benetti, S., Weaver, P. P. E., 
Georgiopoulou, A., Zühlsdorff, C., Amy, L. A., 2007. Onset of submarine debris flow deposition far from original giant landslide. Nature 450, 541-544.

Tappin, D. R., 2010. Submarine mass failures as tsunami sources: their climate control. Philosophical Transactions of the Royal Society 368, 2417-2434.

Tappin, D. R., Watts, P., McMurtry, G. M., Lafoy, Y., Matsumoto, T., 2001. The Sissano, Papua New Guinea tsunami of July 1998 - offshore evidence on the source mechanism. Marine Geology 175, 1-23.

Thomson, J., Weaver, P. P. E., 1994. An AMS radiocarbon method to determine the emplacement time of recent deep-sea turbidites. Sedimentary Geology 89, $1-7$.

Toucanne, S., Zaragosi, S., Bourillet, J.-F., Dennielou, B., Jorry, S. J., Jouet, G., Cremer, M., 2012. External controls on turbidite sedimentation on the glacially-influenced Armorican margin (Bay of Biscay, western European margin). Marine Geology 303-306, 137-153.

Trofimovs, J., Fisher, J. K., Macdonald, H. A., Talling, P. J., Sparks, R. S. J., Hart, M. B., Smart, C. W., Boudon, G., Deplus, C., Komorowski, J.-C., LeFriant, A., Moreton, S. G., Leng, M. L., 2010. Evidence for carbonate platform failure during rapid sea-level rise; ca 14000 year old bioclastic flow deposit in the Lesser Antilles. Sedimentology 57, 735-759.

van Weering, T. C. E., Nielsen, T., Kenyon, N. H., Akentieva, K., Kuijpers, A. H., 1998. Sediments and sedimentation at the NE Faeroe continental margin: contourites and large-scale sliding. Marine Geology 152, 159-176.

Vanneste, M., Mienert, J., Bünz, S., 2006. The Hinlopen Slide: A giant, submarine slope failure on the northern Svalbard margin, Arctic Ocean. Earth and Planetary Science Letters 245, 373-388. 
Voight, B., Janda, R. J., Glicken, H., 1985. Nature and mechanics of the Mount St. Helens rockslide-avalanche of 18 May 1980. In: The 26th U.S. Symposium on Rock Mechanics. American Rock Mechanics Association.

Völker, D., Scholz, F., Geersen, J., 2011. Analysis of submarine landsliding in the rupture area of the 27 February 2010 Maule earthquake, Central Chile. Marine Geology 288, 79-89.

Vorren, T. O., Laberg, J. S., Blaume, F., Dowdeswell, J. A., Kenyon, N. H., Mienert, J., Rumohr, J., Werner, F., 1998. The Norwegian-Greenland sea continental margins: Morphology and late Quaternary sedimentary processes and environment. Quaternary Science Reviews 17 (1-3), 173-302.

Waelbroeck, C., Labeyrie, L., Michel, E., Duplessy, J., McManus, J., Lambeck, K., Balbon, E., Labracherie, M., 2002. Sea-level and deep water temperature changes derived from benthic foraminifera isotopic records. Quaternary Science Reviews 21 (1-3), $295-305$.

Walker, J. R., Massingill, J. V., 1970. Slump features on the Mississippi Fan, Northeastern Gulf of Mexico. Geological Society of America Bulletin 81, 31013108.

Weaver, P. P. E., 1994. Determination of turbidity current erosional characteristics from reworked coccolith assemblages, Canary Basin, north-east Atlantic. Sedimentology 41, 1025-1038.

Weaver, P. P. E., Kuijpers, A., 1983. Climatic control of turbiditic deposition on the Madeira Abyssal Plain. Nature 306, 360-363.

Weaver, P. P. E., Wynn, R. B., Kenyon, N. H., Evans, J., 2000. Continental margin sedimentation, with special reference to the north-east Atlantic margin. Sedimentology 47, 239-256. 
Wien, K., Kölling, M., Schulz, H. D., 2007. Age models for the Cape Blanc Debris Flow and the Mauritania Slide Complex in the Atlantic Ocean off NW Africa. Quaternary Science Reviews 26, 2258-2573.

Wilson, C. K., Long, D., Bulat, J., 2004. The morphology, setting and processes of the Afen Slide. Marine Geology 213 (1-4), 149-167.

Winkelmann, D., Geissler, W., Schneider, J., Stein, R., 2008. Dynamics and timing of the Hinlopen/Yermak Megaslide north of Spitsbergen, Arctic Ocean. Marine Geology 250 (1-2), 34-50.

Wynn, R. B., Weaver, P. P. E., Masson, D. G., Stow, D. A. V., 2002. Turbidite depositional architecture across three interconnected deep-water basins on the north-west African margin. Sedimentology 49, 669-695.

Yokoyama, Y., Lambeck, K., De Deckker, P., Johnston, P., Fifield, L. K., 2000. Timing of the last glacial maximum from observed sea-level minima. Nature 406 (6797), 713-716. 


\section{Figure Captions}

Figure 1: Different sampling strategies for radiocarbon dating of submarine landslides. The rectangles represent sediment cores with hemipelagic background sedimentation (white) and a landslide deposit (grey). Open and filled black circles indicate the position of the sample. A minimum age is obtained by taking one (a) or several samples (b) from the hemipelagic unit above the landslide deposit. A maximum age is obtained when samples are either taken from the hemipelagic unit below (c) or within (d) the failure deposit. A linear average sedimentation rate for the core based on one sample can be significantly different from actual temporary sedimentation rates (e), which can be calculated when several samples between the top of the core and the top of the failure deposit are available. Samples above the deposit can give an age too young if located on a local high (f) and bioturbation on the top as well as erosion at the base of the failed deposit $(\mathrm{g})$ are possible sources of uncertainty to the estimated ages.

Figure 2: Locations of all submarine landslides in the landslide age data base. Different marker shapes represent different depositional regimes (dots: glaciated regions, triangles: river fan systems, rectangles: sediment-starved margins).

Figure 3: Global mean sea level (dark grey curve, Waelbroeck et al., 2002) and global stack of benthic $\delta^{18} O$ records (light grey curve, Lisiecki and Raymo, 2005) plotted with all submarine landslides listed in Table 2 including their individual uncertainty intervals. If available, the age with highest probability is shown by a grey square. The colour of the uncertainty line indicates the sedimentary environment (river fan systems with high terrestrial input, glaciated margins and sediment-starved margins). The grey time line on the upper part of 
the figure indicates the sea level patterns: Sea level fall and lowstand from 180$136 \mathrm{ka}$ BP, sea level rise and highstand during Termination II (136-122 ka BP), sea level fall (122-22 ka BP), the Last Glacial Maximum (LGM) from 22-18 ka BP followed by a sea level rise (18-6 ka BP) and the modern sea level highstand (60 ka BP).

Figure 4: Global mean sea level (light grey) and time line (top) as in Fig. 3 and histogram representation of submarine landslides based on the most likely ages (dark grey bars) as well as taking into account the uncertainty interval, assuming an evenly distributed probability along this interval (open bars with black edges). The bin width is $5 \mathrm{ky}$.

Figure 5: Histograms of the assumed non-biased part of the data set plotted with bin widths of $2 \mathrm{ky}$ (a) and $1 \mathrm{ky}$ (b) following the same notation as in Fig. 4. Panel c) shows the number of histogram bins expected to have $j=0-10$ events $\left(E_{j}\right)$ according to the Poisson model (black lines and dots) as opposed to the observed number of histogram bins with $j$ landslides from the landslide data set (grey lines and dots). The continuous lines represent a $2 \mathrm{ky}$ bin width whilst the dashed lines show the results for 1 ky bins.

Figure 6: Probabilities for the maximum number of landslides in one histogram bin (a), maximum difference in number of landslides between two neighbouring bins (b) as well as the number of neighbouring bins with more than the average number of landslides (c) for randomly distributed samples and a histogram bin size of $5 \mathrm{ky}$. Probabilities for the same characteristics are also shown for histogram bin sizes of $2 \mathrm{ky}(\mathrm{d}, \mathrm{e}, \mathrm{f})$ and $1 \mathrm{ky}(\mathrm{g}, \mathrm{h}, \mathrm{i})$. The arrows indicate the numbers observed in the landslide data base. 
Figure 7: Histogram representation as in Fig. 4 for subsets of the landslide data set (notation identical to Fig. 4): (a) glaciated margins, (b) river fan systems with large sediment input, (c) sediment-starved margins and (d) failures off the coast of north-west Africa. The grey curves depict global mean sea level (Waelbroeck et al., 2002) and $n$ is the number of landslides in the respective subset.

Figure 8: Histograms of the river fan systems subset (Fig. 7b) plotted with bin widths of $2 \mathrm{ky}$ (a) and $1 \mathrm{ky}$ (b) following the same notation as in Fig. 5. Panel c) shows the number of histogram bins expected to have $j=0-8$ events $\left(E_{j}\right)$ according to the Poisson model (black lines and dots) as opposed to the observed number of histogram bins with $\mathrm{j}$ landslides from the landslide data set (grey lines and dots). The continuous lines represent a $2 \mathrm{ky}$ bin width whilst the dashed lines show the results for 1 ky bins.

Figure 9: Probabilities of various characteristics for randomly distributed samples with the same sample size as the river fan systems subset, following the notation of Fig. 6. The arrows highlight the numbers observed in the river fan systems subset.

Figure 10: Sea level curve (grey) after Waelbroeck et al. (2002), timing of submarine landslides (squares) with uncertainty intervals (thin solid lines) and accumulation rates over time (dashed lines). Note the logarithmic scale in the uppermost panel. 
Tables

\begin{tabular}{lccl}
\hline Area & Max core length [m] & Max age [ka] & Reference \\
\hline Balearic abyssal plain & 36.0 & $>50.0$ & Rothwell et al. (1998) \\
Heradotus basin & 26.0 & 28.8 & Reeder et al. (2000) \\
Iberian margin & 4.4 & 23.0 & Gracia et al. (2010), Masson et al. (2011) \\
Nile & 29.0 & 120.0 & Ducassou et al. (2007) \\
Makran & 33.0 & 21.6 & Bourget et al. (2011) \\
Indus & 9.2 & 40.0 & Bourget et al. (2013) \\
\hline
\end{tabular}

Table 1: Approximate lengths of cores recovering turbidites or slide deposits and maximum obtained ages. 


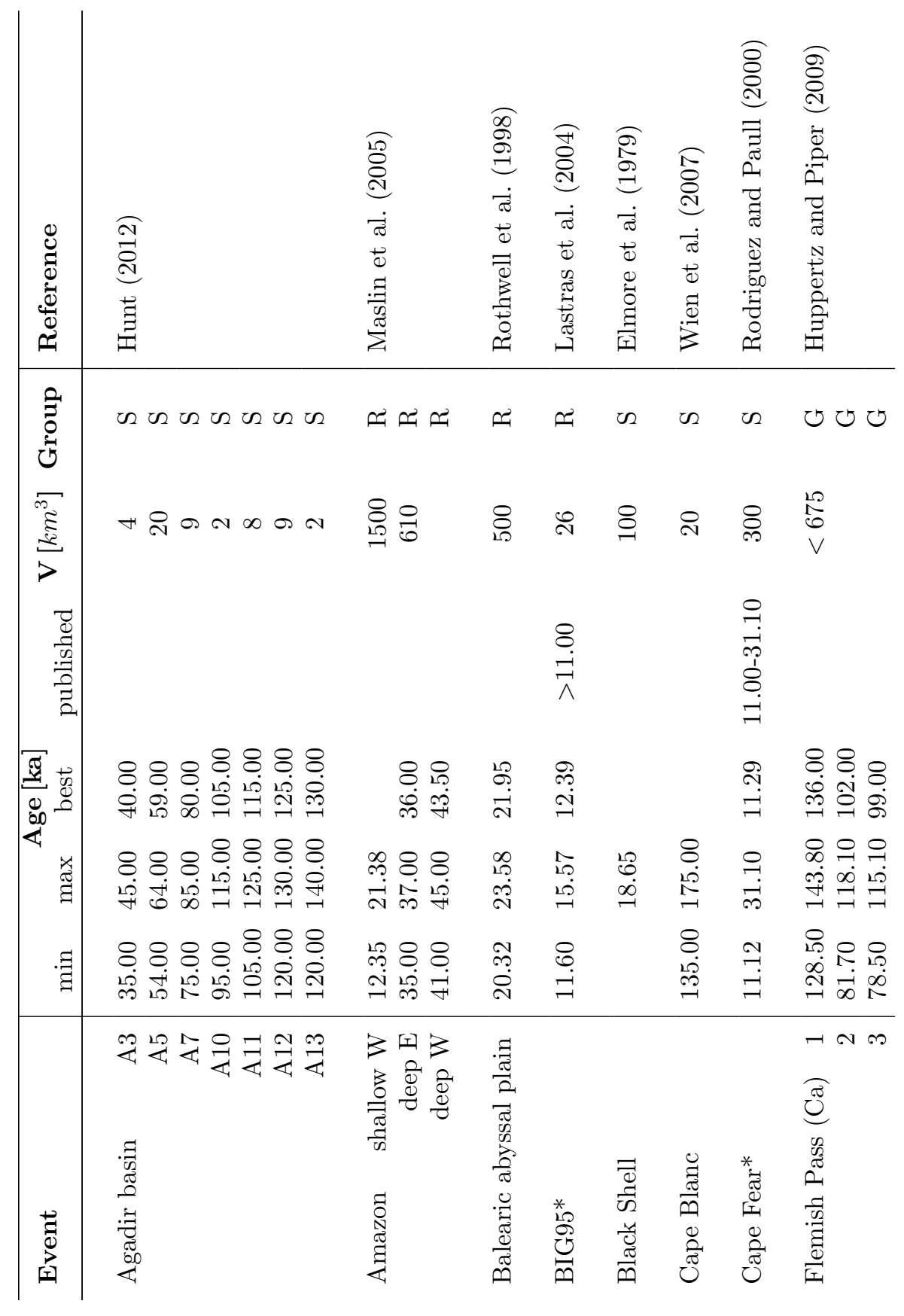




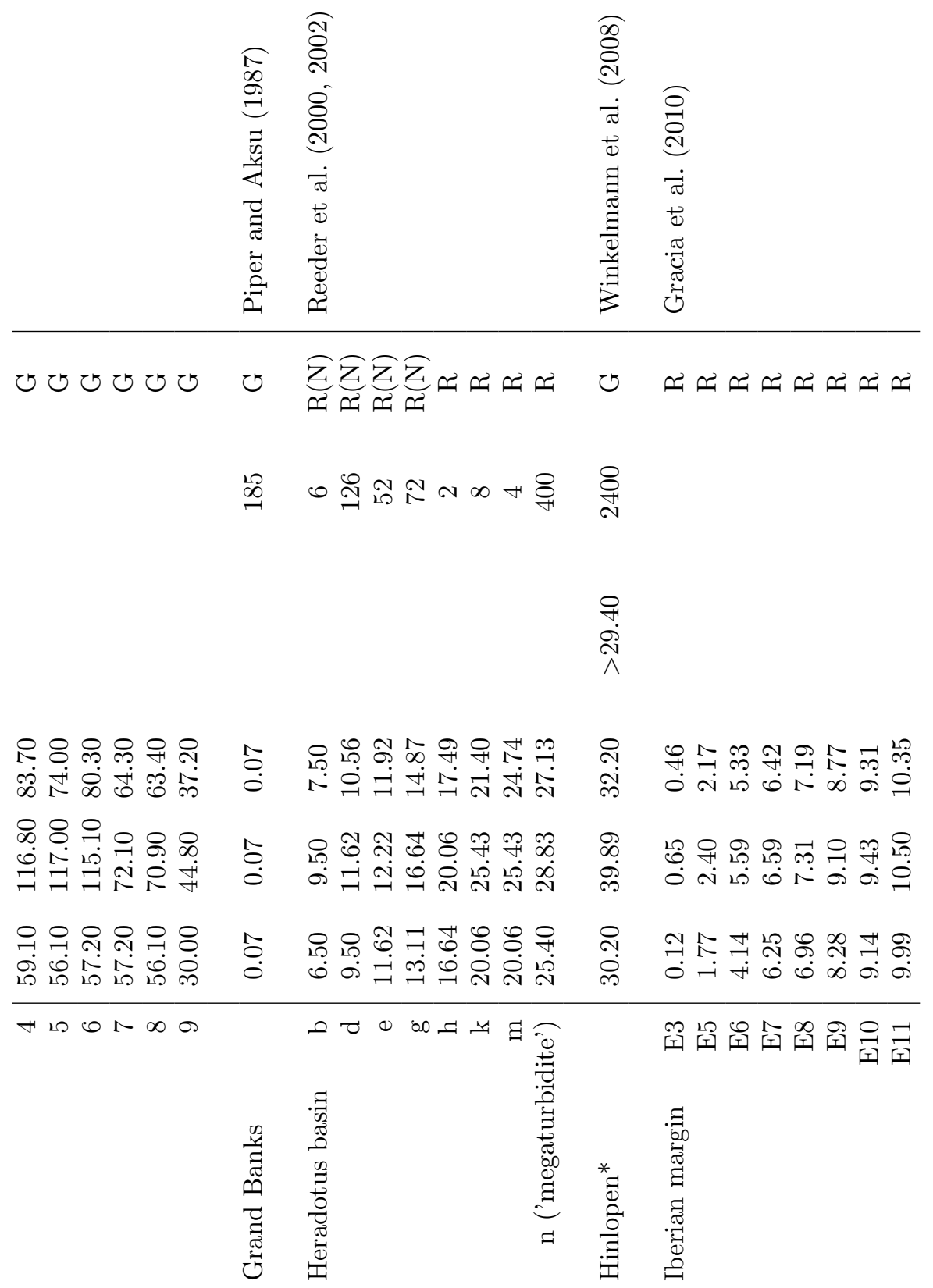




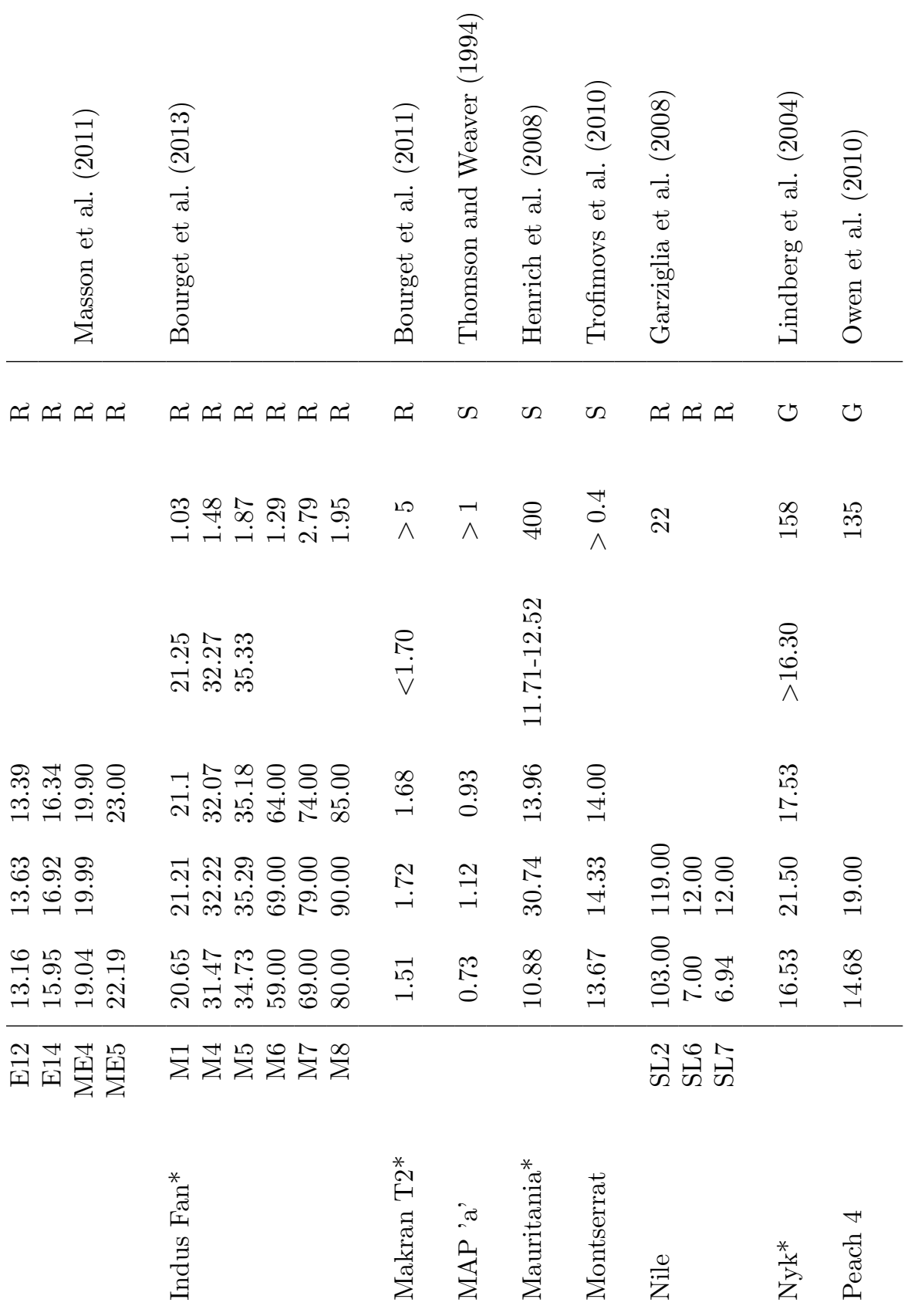




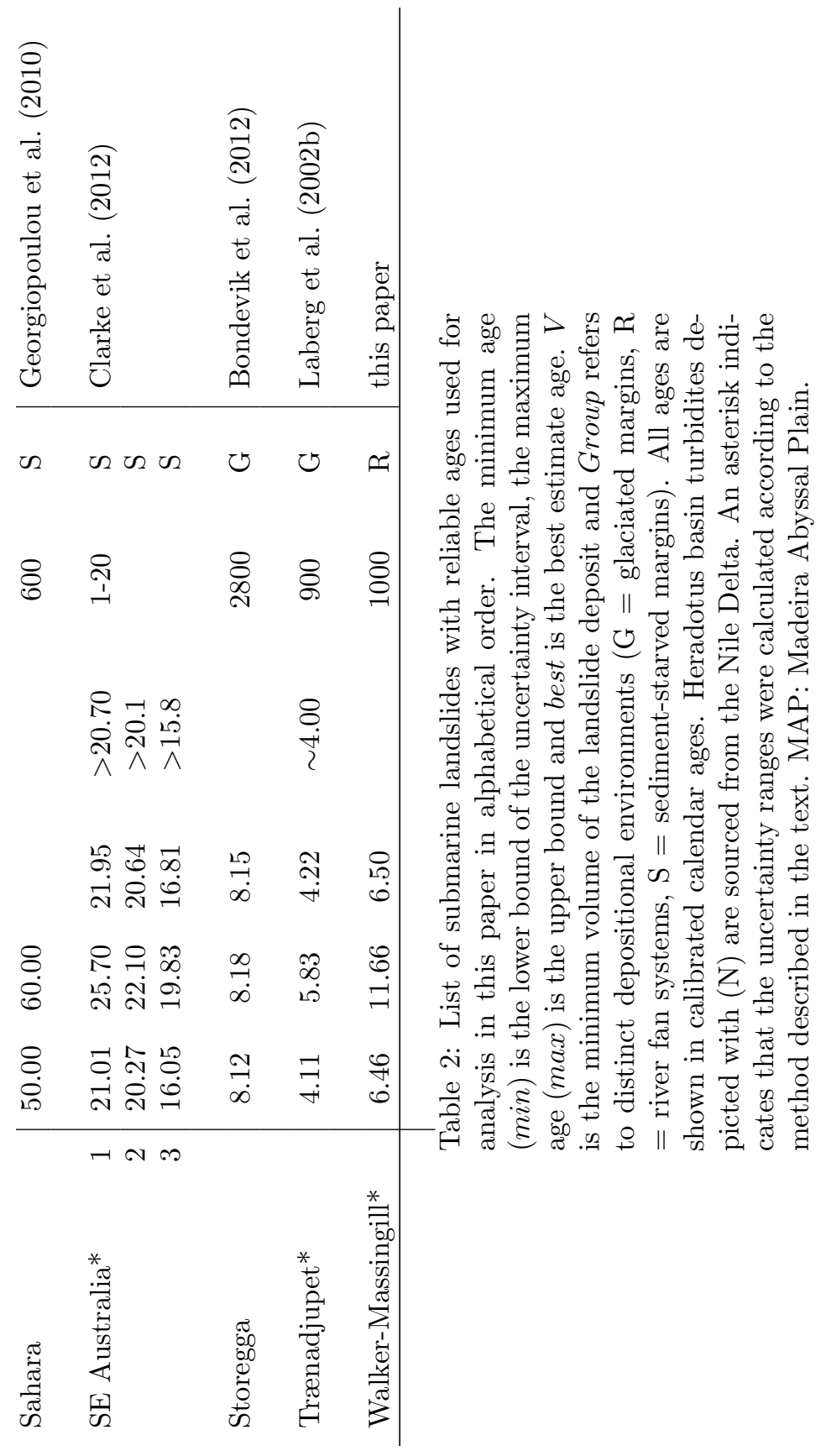




\begin{tabular}{|c|c|c|}
\hline Landslide Area & Sedimentation Rate $[\mathrm{m} / \mathrm{ky}]$ & Reference \\
\hline Agadir basin & 0.02 & Bozzano et al. (2002) \\
\hline Amazon & 4.41 (34-10 ka), 0.45 (105-3 ka) & Mikkelsen et al. (1997) \\
\hline Balearic abyssal plain & $\begin{array}{l}0.33 \quad(50-21 \mathrm{ka}), \quad 3.50 \quad(21-20 \mathrm{ka}), \\
0.27(<20 \mathrm{ka})\end{array}$ & Rothwell et al. (2000) \\
\hline BIG95 & $\begin{array}{l}1.00(>22 \mathrm{ka}), 1.75(22-18 \mathrm{ka}), 1.00 \\
(18-11 \mathrm{ka}), 0.63(<11 \mathrm{ka})\end{array}$ & Nelson (1990) \\
\hline Black Shell & 0.12 (<12 ka), 0.24 (glacials) & Balsam (1981) \\
\hline Cape Blanc & $\begin{array}{l}0.11 \quad(200-193 \mathrm{ka}), 0.15 \quad(193- \\
183 \mathrm{ka}), 0.09(183-152.5 \mathrm{ka}), 0.12 \\
(152.5-142.0 \mathrm{ka}), 0.17(142-135 \mathrm{ka})\end{array}$ & $\begin{array}{l}\text { Sarnthein and Tiedemann } \\
(1989)\end{array}$ \\
\hline Cape Fear & 0.20 & Paull et al. (1996) \\
\hline Flemish Pass & $\begin{array}{l}0.70 \text { (>122 ka), } 0.18 \text { (122-50 ka), } \\
0.21 \text { (50-26 ka) }\end{array}$ & Huppertz and Piper (2009) \\
\hline Grand Banks & $0.10(<26 \mathrm{ka})$ & Huppertz and Piper (2009) \\
\hline Heradotus basin & $\begin{array}{l}0.05(>28 \mathrm{ka}), 2.00(28-17 \mathrm{ka}), 1.00 \\
(17-6 \mathrm{ka}), 0.15(6-0 \mathrm{ka})\end{array}$ & Reeder et al. (2000) \\
\hline Hinlopen & $0.04-0.20$ & Winkelmann et al. (2008) \\
\hline Iberian margin & $\begin{array}{l}0.54 \quad(50-25 \mathrm{ka}), \quad 1.08 \quad(25-8 \mathrm{ka}), \\
0.23 \text { (<8 ka) }\end{array}$ & Lebreiro et al. (2009) \\
\hline Indus Fan & $1.65(25-12 \mathrm{ka})$ & Bourget et al. (2011) \\
\hline Makran & $1.65(25-12 \mathrm{ka}), 0.90(<12 \mathrm{ka})$ & Bourget et al. (2011) \\
\hline MAP & 0.02 & Bozzano et al. (2002) \\
\hline Mauritania & $\begin{array}{l}0.12 \quad(50-27 \mathrm{ka}), \quad 0.25 \quad(27-15 \mathrm{ka}), \\
0.20(<15 \mathrm{ka})\end{array}$ & $\begin{array}{l}\text { Sarnthein and Tiedemann } \\
(1989)\end{array}$ \\
\hline Montserrat & $0.01-0.10$ & Reid et al. (1996) \\
\hline Nile & $\begin{array}{lrrr}0.10 & (127-70 \mathrm{ka}), & 0.03 & (70-25 \mathrm{ka}), \\
0.02 & (25-14.8 \mathrm{ka}), \quad 0.20 & (14.8- \\
12 \mathrm{ka}), & 1.50 & (12-8 \mathrm{ka}), & 0.30 \\
(<8 \mathrm{ka}) & & & \end{array}$ & Ducassou et al. (2009) \\
\hline Nyk & $<1.20$ (Nyk drift) & al. (2005) \\
\hline Peach 4 & $0.40-2.00(26-19 \mathrm{ka})$ & Knutz et al. (2002) \\
\hline Sahara & 0.12 (91-74 ka), 0.12 (50-27 ka) & $\begin{array}{l}\text { Sarnthein and Tiedemann } \\
(1989)\end{array}$ \\
\hline SE Australia & $\begin{array}{l}0.05 \quad(34-25 \mathrm{ka}), \quad 0.16 \quad(25-11 \mathrm{ka}), \\
0.05 \quad(<11 \mathrm{ka})\end{array}$ & Jenkins and Keene (1992) \\
\hline Storegga & $\begin{array}{l}1.40(>24.5 \mathrm{ka}), 2.7(24.5-18.9 \mathrm{ka}) \\
36.0(18.9-18.6 \mathrm{ka}), 27.00 \quad(18.6- \\
17.8 \mathrm{ka}), 1.10(<17.8 \mathrm{ka})\end{array}$ & Hjelstuen et al. (2004) \\
\hline Trænadjupet & $\begin{array}{l}0.70 \text { (26-21 ka), } 1.10 \text { (21-19 ka), } \\
2.20 \text { (19-18 ka), } 0.18 \text { (18-0 ka) }\end{array}$ & Rørvik et al. (2010) \\
\hline Walker-Massingill & $\begin{array}{l}5.00(42-24 \mathrm{ka}), 12.00(24-16 \mathrm{ka}), \\
4.00(16-11 \mathrm{ka}), 1.00(<11 \mathrm{ka})\end{array}$ & Flemings et al. (2006) \\
\hline
\end{tabular}

Table 3: Variation of sedimentation rates over time in the landslide source area. 


\begin{tabular}{lccc}
\hline Failure & Delay $[\mathrm{ky}]$ & Max delay $[\mathrm{ky}]$ & Min delay $[\mathrm{ky}]$ \\
\hline Amazon & 20.9 & 21.6 & 12.5 \\
BIG95 & 9.6 & 10.4 & 6.4 \\
Black Shell & & & 7.35 \\
Heradotus basin (endmembers) & 0.9 & 2.6 & 0 \\
& 20.5 & 21.5 & 18.5 \\
Iberian margin (endmembers) & 2.0 & 2.8 & 2.4 \\
& 24.5 & 24.9 & 24.3 \\
Makran & 23.3 & 23.5 & 23.3 \\
Mauritania & 13.0 & 16.1 & 0 \\
Nile & 2.5 & 5.5 & 0 \\
SE Australia 1 & 3.1 & 4.0 & 0 \\
SE Australia 2 & 4.4 & 4.7 & 2.9 \\
SE Australia 3 & 8.2 & 9.0 & 5.2 \\
Storegga & 10.8 & 10.8 & 10.7 \\
Trænadjupet & 14.8 & 14.9 & 13.2 \\
Walker-Massingill & 17.5 & 17.5 & 12.3 \\
\hline
\end{tabular}

Table 4: Delay between onset of increased sedimentation on the continental slope and best estimate age, minimum and maximum age of landslides for examples shown in Fig. 10. 


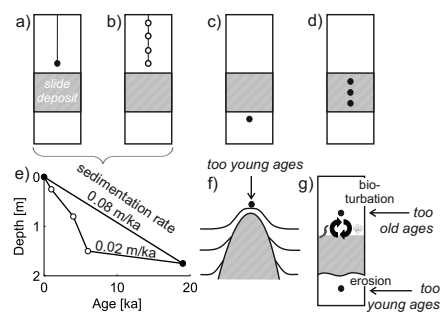

Figure 1:

Figures 


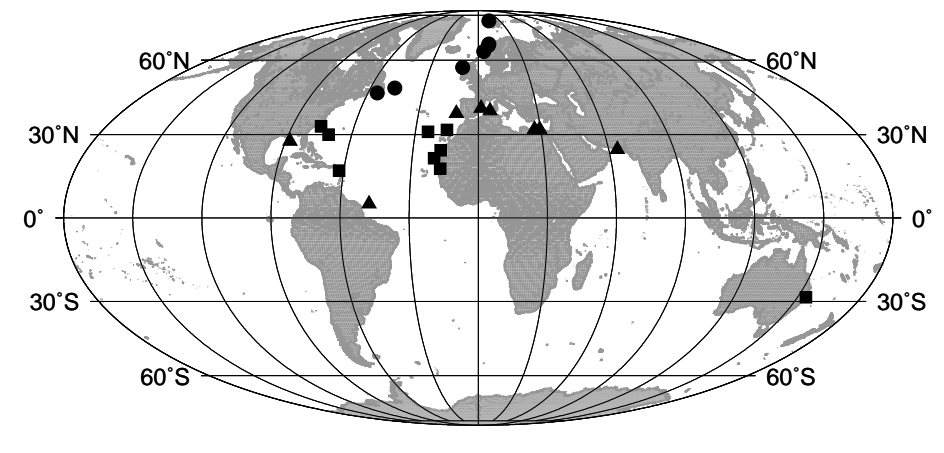

Figure 2: 


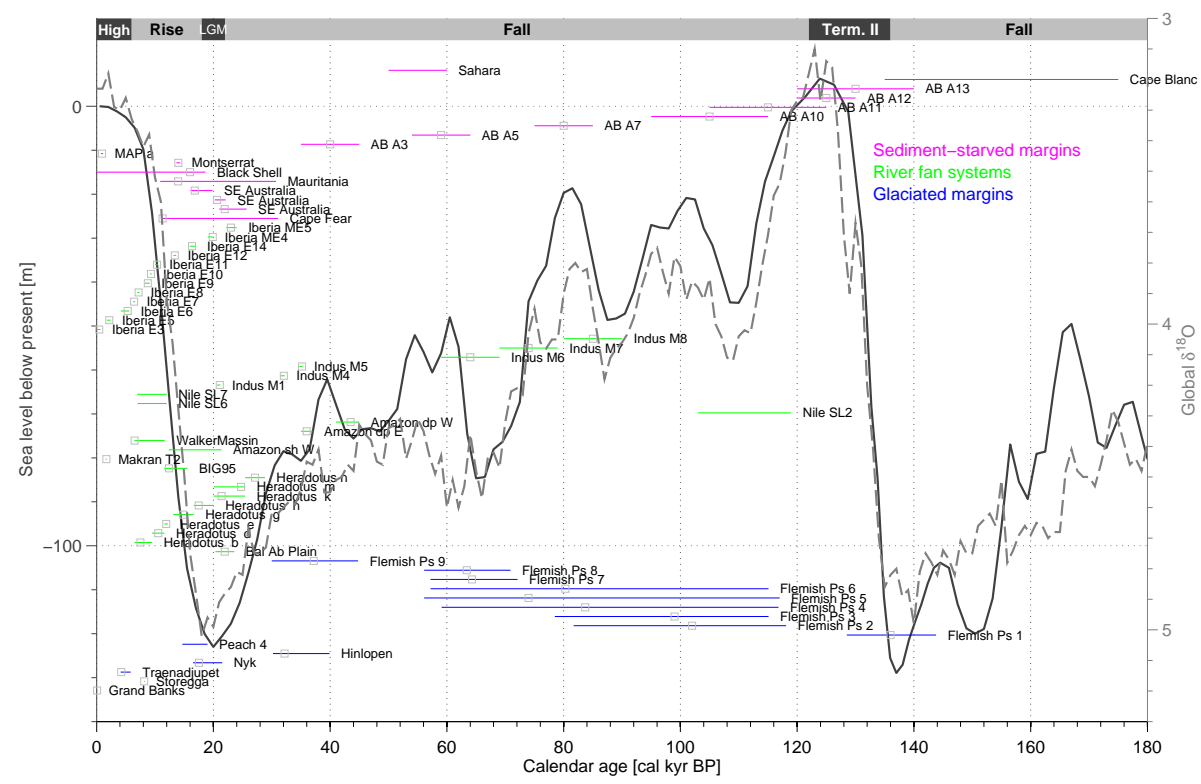

Figure 3: Reproduce in colour on the Web and in black-and-white in print

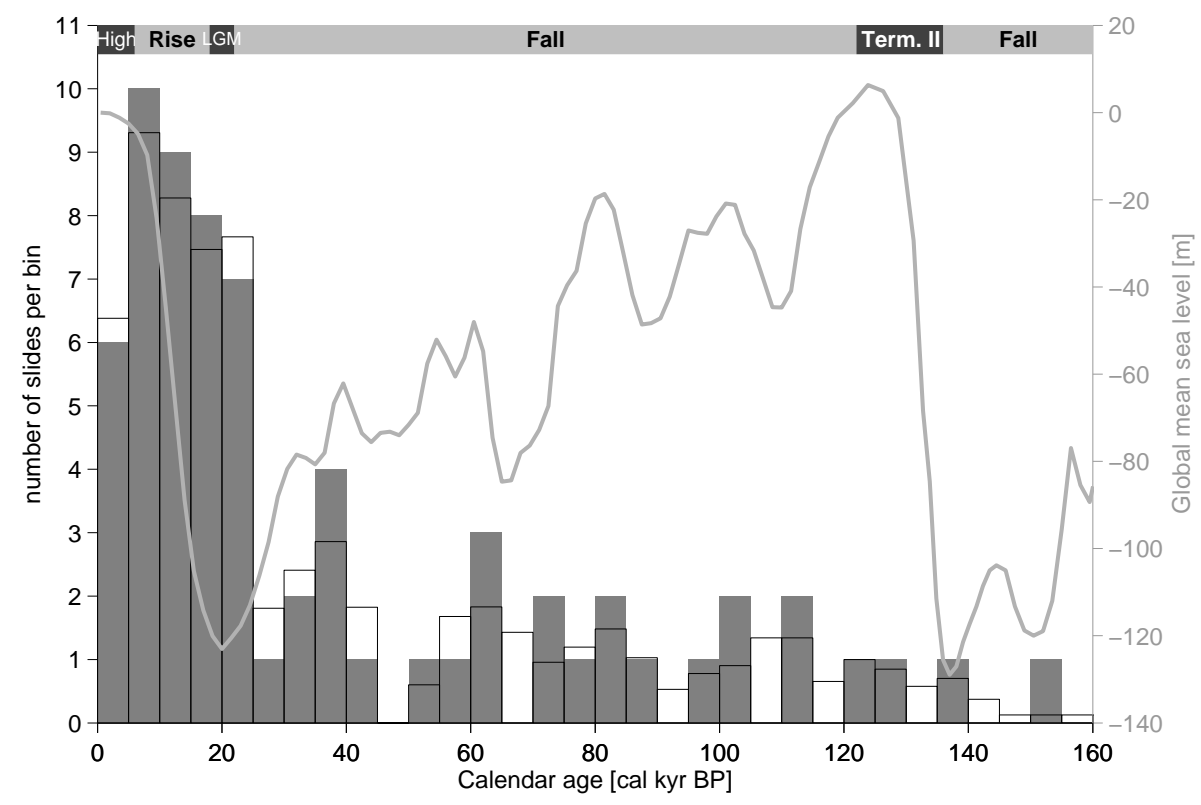

Figure 4: 

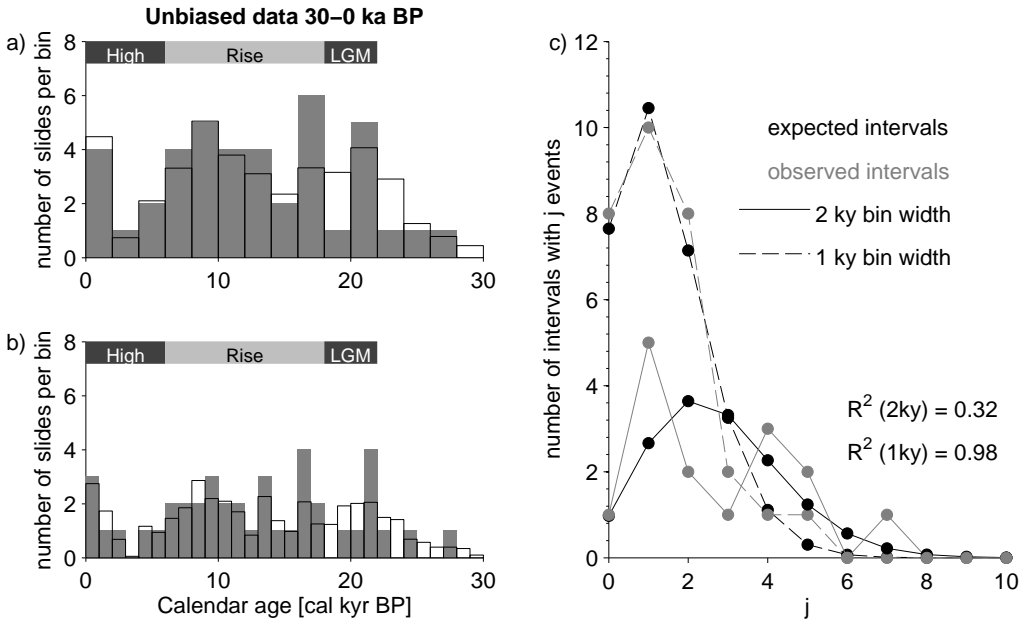

Figure 5:
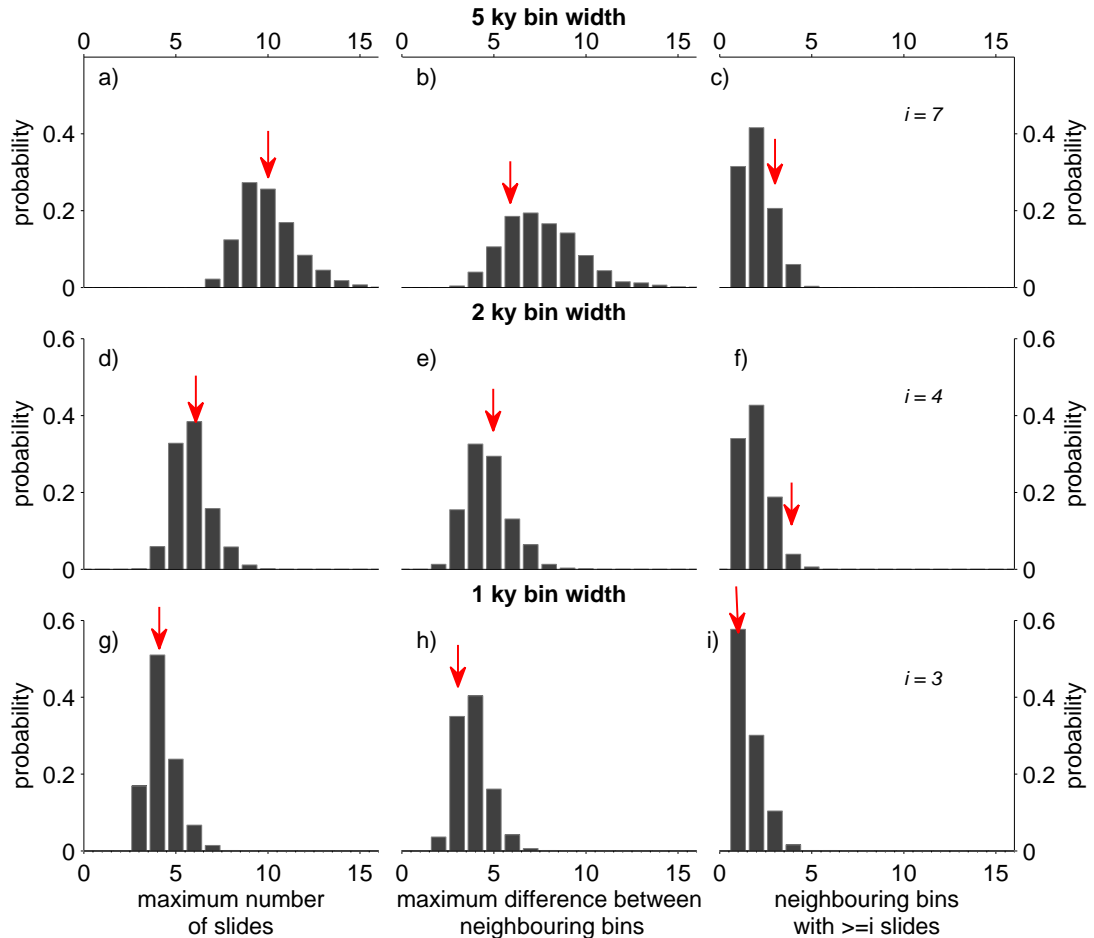

Figure 6: Reproduce in col or on the Web and in black-and-white in print 
a) Glaciated Margins

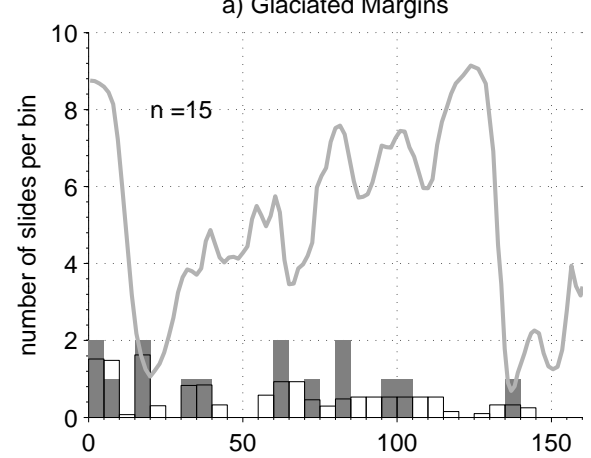

c) Sediment-starved Margins

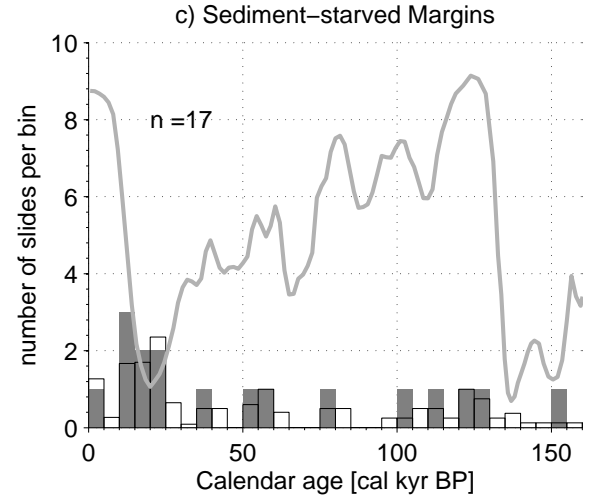

b) River Fan Systems

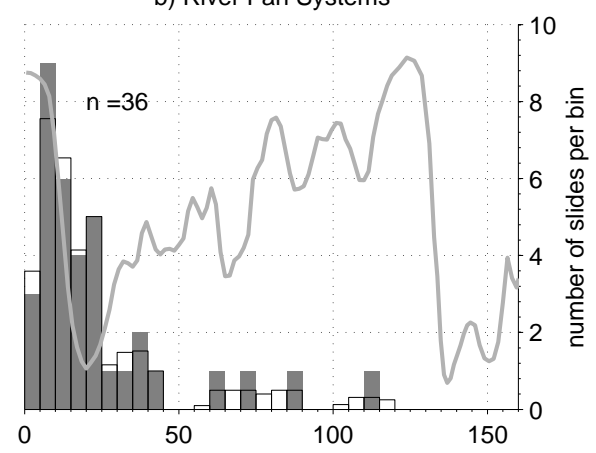

d) Northwest African Margin

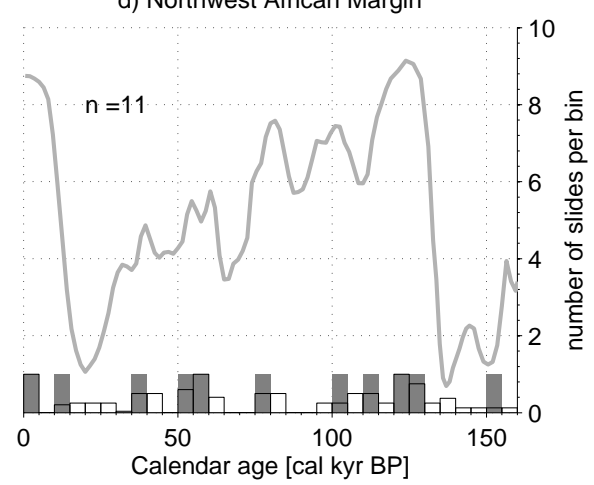

Figure 7:
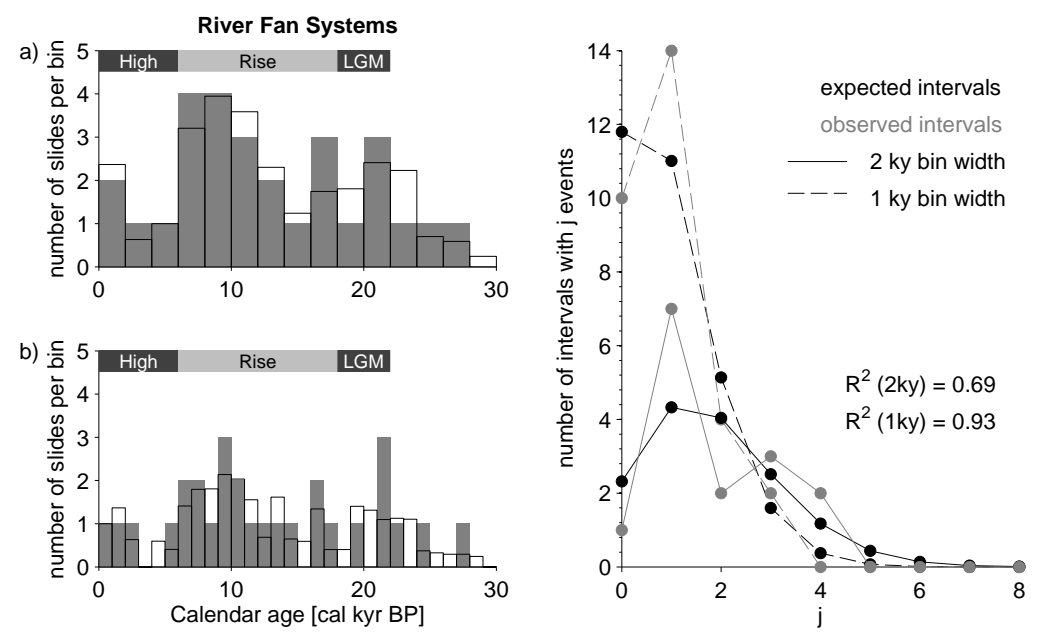

Figure 8: 

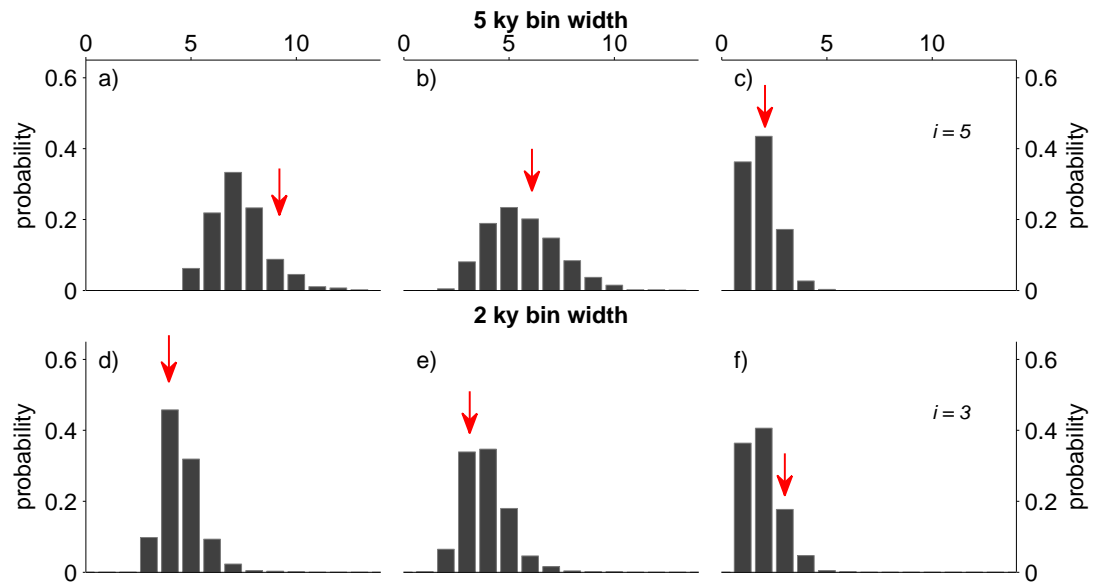

e)

2 ky bin width
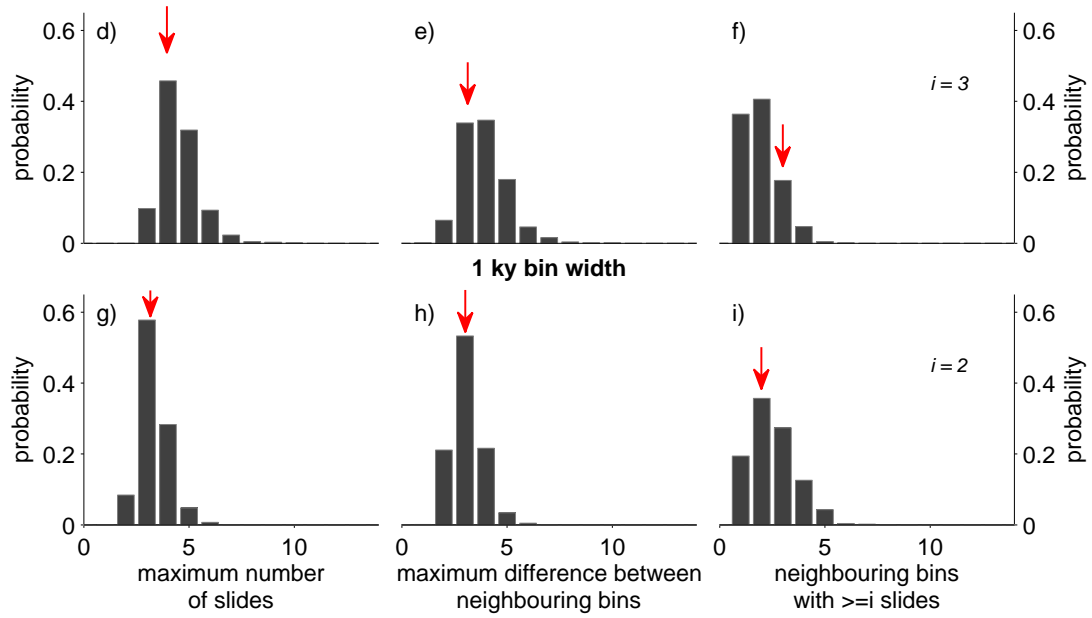

Figure 9: Reproduce in col or on the Web and in black-and-white in print 


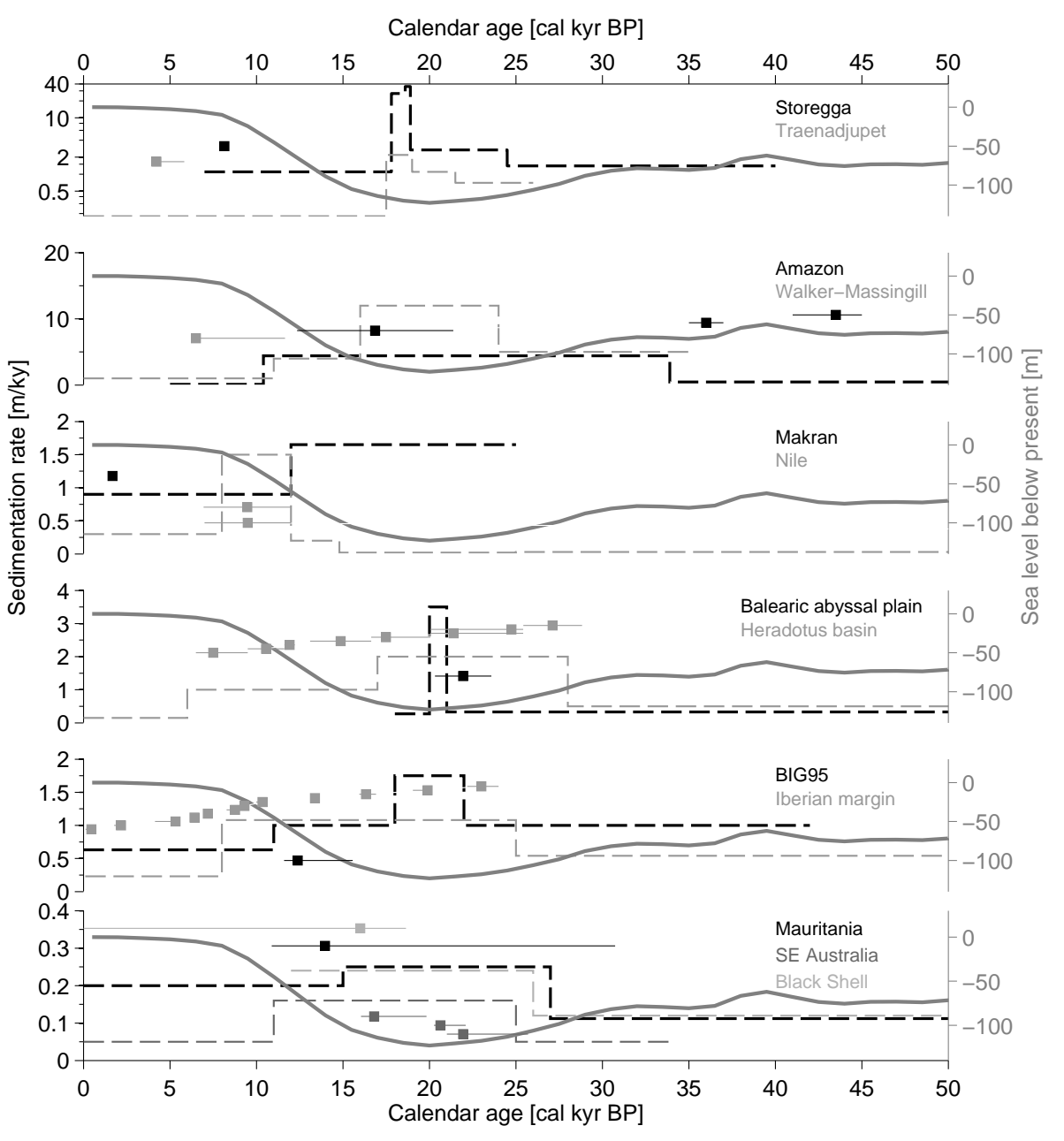

Figure 10: 